\title{
37. NEOGENE BENTHIC FORAMINIFER BIOSTRATIGRAPHY AND DEEP-WATER HISTORY OF SITES 645, 646, AND 647, BAFFIN BAY AND LABRADOR SEA ${ }^{1}$
}

\author{
M. A. Kaminski, ${ }^{2}$ F. M. Gradstein,,$^{2,3}$ D. B. Scott, ${ }^{2}$ and K. D. Mackinnon ${ }^{2}$
}

\begin{abstract}
Benthic foraminifers were examined from Neogene sediments of Ocean Drilling Program (ODP) Sites 645, 646, and 647 to determine their biostratigraphy and to place constraints on the paleoceanographic history of Baffin Bay, Eirik Ridge, and the Gloria Drift.

At Site 645 in Baffin Bay, a Pleistocene Stetsonia assemblage is similar to the modern Baffin Bay assemblage, but an underlying Epistominella takayanagii assemblage has no modern analog. Miocene assemblages below a barren interval display low diversity and consist mainly of agglutinated species.

At Site 646 in the Labrador Sea, benthic faunal turnovers occur near important seismic horizons. A Miocene Nuttallides umbonifera assemblage similar to assemblages at other North Atlantic sites occurs below reflector R3. Above reflector R3, a coarse agglutinated assemblage containing more diversified calcareous benthic foraminifers was found that displays affinity to assemblages in the Norwegian-Greenland Sea. The faunal turnover near reflector R3 was interpreted as reflecting the onset (or renewal) of significant Denmark Straits Overflow Water at Site 646 at $\sim 7.5 \mathrm{Ma}$. Agglutinated species disappear between reflector R2 and the base of the sediment drift, indicating a change in deep-water properties that occurred at $\sim 4.7 \mathrm{Ma}$. This turnover ultimately may be linked to the reopening of the Mediterranean. The beginning of drift sedimentation at the Eirik Ridge is dated at $\sim 4.5 \mathrm{Ma}$. Drift formation ceased at $\sim 2.5 \mathrm{Ma}$, concomitant with the appearance of ice-rafted sediments. Pleistocene assemblages containing Stetsonia horvathi display affinity to deep assemblages in high-latitude ocean basins.

Upper Pliocene and Pleistocene benthic assemblages at Site 647 contain N. umbonifera, which indicates a continued influence of corrosive deep water at the Gloria Drift.
\end{abstract}

\section{INTRODUCTION}

One of the main objectives of Leg 105 drilling in Baffin Bay and the Labrador Sea was to recover a continuous record of Neogene sediments, which are required to investigate the nature of the faunal response to circulation changes and to climatic deterioration leading to the onset of Northern Hemisphere glaciation. Baffin Bay and the Labrador Sea serve as conduits for the exchange of water and heat between the Arctic and North Atlantic oceans. Another important goal of Leg 105 was to provide insight into the nature of surface- and deep-water connections between the Atlantic and Arctic via the Baffin Bay corridor. Since the distribution of microfossils in pelagic marine sediments can be related to water-mass characteristics, the history of past circulation patterns can be interpreted from the micropaleontologic record of these basins. Thick sequences of Neogene sediments were recovered by means of hydraulic piston coring and rotary drilling at three sites: Site 645 in Baffin Bay and Sites 646 and 647 in the Labrador Sea (Fig. 1).

Pleistocene sediments from the Baffin Bay area are known only from shallow piston cores (Aksu, 1983) and exploration wells off Baffin Island (Klose et al., 1982) and from the Davis Straits area drilled by the Greenland Geological Survey (Henderson et al., 1982). Micropaleontological data from pre-Pleistocene sediments of Baffin Bay were unavailable, and it was not known whether foraminifer assemblages display closer affinities to the North Atlantic or to the Arctic.

The deep Labrador Sea was drilled during DSDP Leg 12 (Laughton, Berggren, et al., 1972), and the foraminifer data

\footnotetext{
${ }^{1}$ Srivastava, S. P., Arthur, M., Clement, B., et al., 1989. Proc. ODP, Final Repts. (Pt. B), 105: College Station, TX (Ocean Drilling Program).

2 Centre for Marine Geology, Dalhousie University, Halifax, Nova Scotia B3H 3J5, Canada.

3 Atlantic Geoscience Centre, Bedford Institute of Oceanography, Dartmouth, Nova Scotia B2Y 4A2, Canada.
}

from this area were summarized by Berggren and Schnitker (1983). Drilling during ODP Leg 105 was undertaken near two prominent sediment drifts in the Labrador Sea. The major paleontologic objectives at Sites 646 and 647 were (1) to provide a biostratigraphic framework for dating important seismic reflectors and (2) to study the nature of deep circulation over the Eirik Ridge and Gloria Drift.

For comparison, we also present the foraminifer record determined in cutting samples from the Texaco Blue-H28 well on the Labrador margin (Fig. 1). This well is one of the few commercial wells along the Canadian Atlantic Margin that has a deep marine upper Miocene to Pliocene stratigraphic record.

\section{SAMPLE LOCALITIES AND LITHOSTRATIGRAPHY}

The following summary of lithologic units and seismic stratigraphy derives from Srivastava et al. (1987). Site 645 lies on the continental slope off southern Baffin Island at a water depth of $2020 \mathrm{~m}$. Drilling at Site 645 penetrated $1147.1 \mathrm{~m}$ of sediment to provide a continuous lower Miocene to Pleistocene stratigraphic record. The entire lithologic sequence in Holes $645 \mathrm{~B}, 645 \mathrm{D}$, and $645 \mathrm{E}$ has a pronounced terrigenous character and was subdivided into three lithologic units. (Fig. 2)

Lithologic Unit I consists of alternating beds of light tan to gray calcareous gravel-bearing muddy sand and dark gray silty mud having scattered dropstones. This unit occurs from 0 to 168.1 meters below sea floor (mbsf), and its age was determined as early Pleistocene to Holocene, based on dinoflagellates.

Lithologic Unit II extends from 168.1 to $330.7 \mathrm{mbsf}$ and consists of noncalcareous silty mud with dropstones. Its age was determined as late Pliocene to early Pleistocene, based on dinoflagellates.

Lithologic Unit III extends from 330.7 to $1147.1 \mathrm{mbsf}$ and is early Miocene to late Pliocene in age, based on dinoflagellates and scattered calcareous planktonic microfossils. Subunit IIIA 


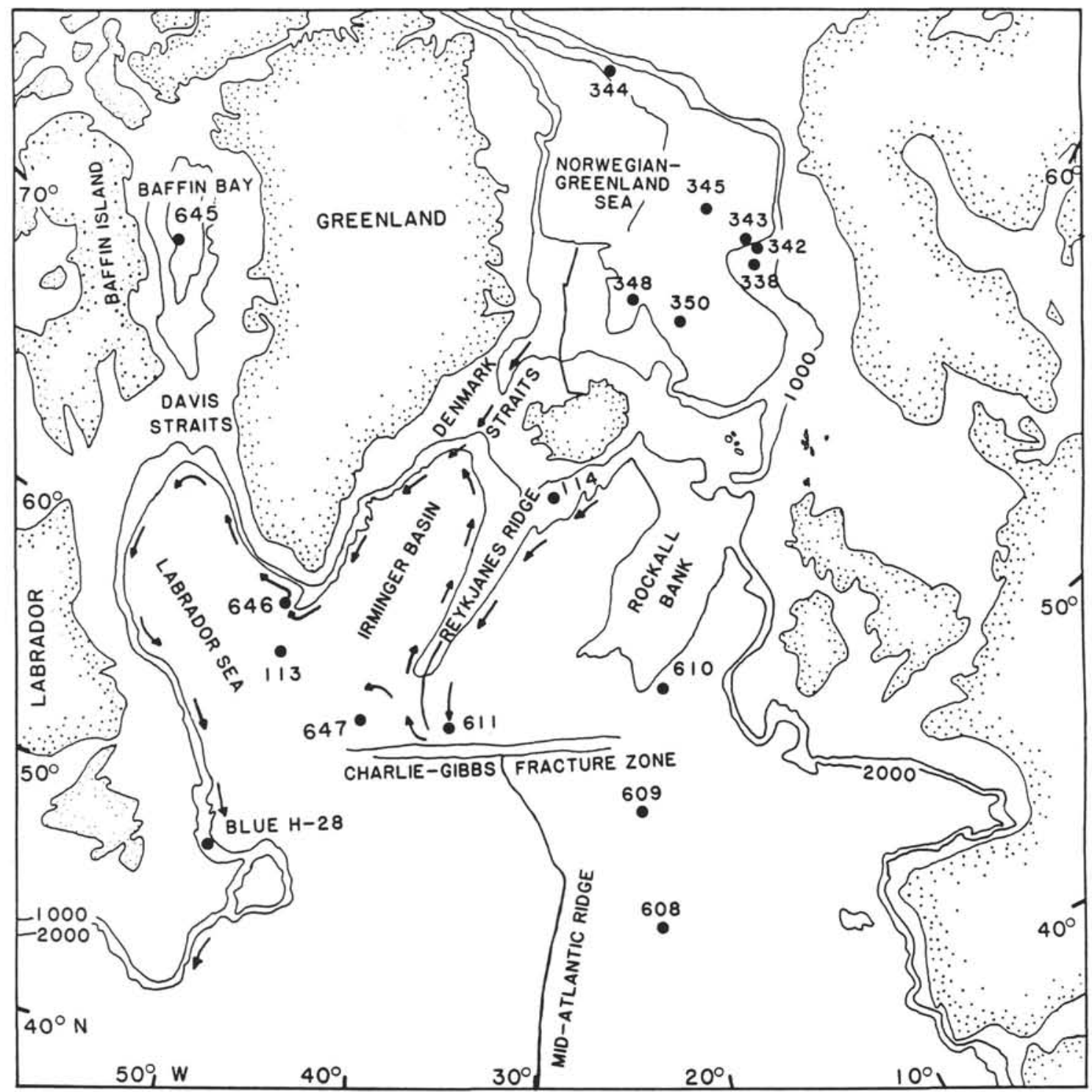

Figure 1. Location of ODP Leg 105 sites in the Labrador Sea and Baffin Bay and other sites and exploration wells discussed in the text. Arrows indicate inferred direction of deep circulation in the western North Atlantic. Base map is after Srivastava and Tapscott (1986), bathymetry in meters.

consists mainly of poorly sorted olive-gray silty mudstone and muddy sandstone. Scattered pebbles occur to a depth of 605 mbsf. Subunit IIIB contains calcareous silty claystones that have an organic carbon content of about $3 \%$ interbedded with muddy sandstones. Subunit IIIC consists of fine- to mediumgrained muddy sandstone and silty mudstones.

Site 646 was drilled in $3450 \mathrm{~m}$ of water on the northwest flank of the Eirik Ridge, a prominent sediment drift located off the southern tip of Greenland. The Eirik Ridge is a current-generated feature that occurs near the present pathway of Denmark Straits Overflow Water (Fig. 1). Drilling in Hole 646B recovered $766.7 \mathrm{~m}$ of terrigenous silty clays and silts having varying amounts of biogenic components. Dropstones are present to a depth of $236.4 \mathrm{mbsf}$ and define the base of lithologic Unit I. Biogenic silica is present to a depth of $330 \mathrm{mbsf}$. Lithologic Unit II extends from 236.4 mbsf to the base of Hole 646B and consists of silty claystones and clayey siltstones having layers that contain up to $50 \%$ or $60 \%$ nannofossils.

Prominent seismic reflectors subdivide the sedimentary record of Hole 646B into four major seismic units (Srivastava, Ar- thur, et al., 1987). Seismic reflector R1 defines the base of seismic Unit 1 and corresponds to a lithologic break between icerafted sediments and pre-glacial Pliocene sediments below. Thus, seismic Unit 1 coincides with lithologic Unit I. Seismic Unit 2 encompasses the drift sequence between 236.4 and 377 mbsf. The base of seismic Unit 2 in Hole 646B lies conformably on seismic Unit 3 and delineates the base of the sediment drift sequence visible in seismic profiles across the Eirik Ridge. Locally, the base of seismic Unit 2 is expressed as an erosional unconformity, but there is no evidence of a hiatus in Hole 646B. Reflector R2 corresponds to a change in carbonate content at $\sim 500$ mbsf, about $0.05 \mathrm{~s}$ below the top of seismic Unit 3 . Seismic Unit 3 extends from 377 to $680 \mathrm{mbsf}$, and its base is delineated by seismic reflector R3. Reflector R3 is actually a couple of closely spaced reflectors that correspond to changes in the carbonate content of the sediments at 680 and 710 mbsf. Below 710 mbsf, the sediments of seismic Unit 4 are composed of dark gray silty claystones having carbonate contents below $10 \%$.

Site 647, the southernmost site drilled during Leg 105, is located about $200 \mathrm{~km}$ south of the Gloria Drift at a water depth 


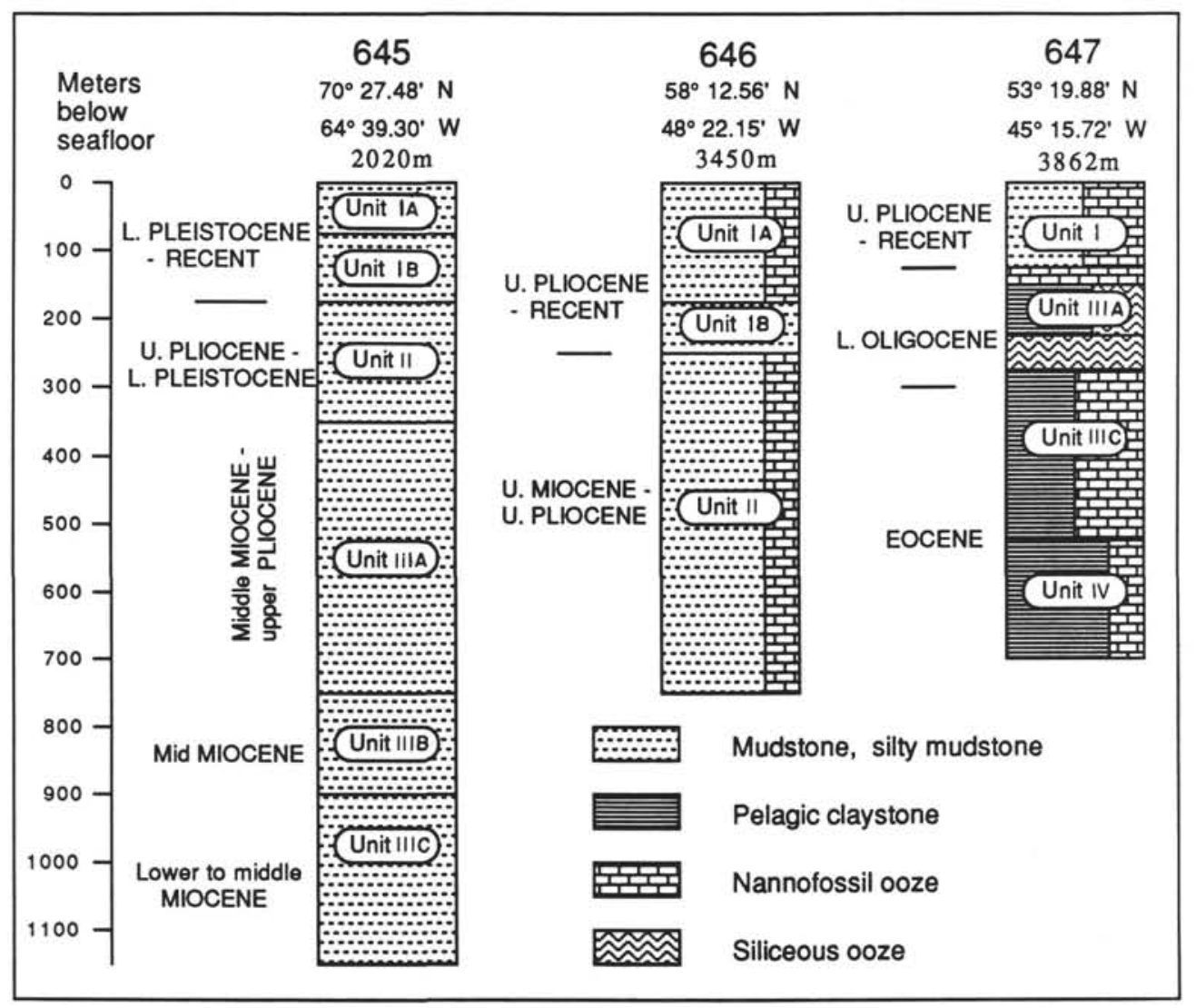

Figure 2. Lithostratigraphy at Sites 645, 646, and 647 .

of $3862 \mathrm{~m}$. Drilling at this site recovered a 116-m section of upper Pliocene to Holocene silty nannofossil clays and interbedded gravel-bearing silts that represent depositional cycles related to glacial-interglacial cycles. These sediments overlie an upper Miocene to upper Pliocene hiatus that corresponds to a regional seismic reflector.

The Texaco Blue H-28 well was drilled in $1486 \mathrm{~m}$ of water on the northeastern Grand Banks near Orphan Knoll. The well is situated near the present axis of the Western Boundary Undercurrent, a site of rapid sedimentation in the late Neogene. The Cenozoic microfossil record reflects deposition in midbathyal water depths, which sediments from this well has probably occupied since the Late Cretaceous.

\section{METHODS}

The chronostratigraphic framework for benthic foraminifer biostratigraphy in Hole 646B is based on magnetic reversal, nannofossil and diatom stratigraphy, (Shipboard Scientific Party, 1987a) and planktonic foraminifer datums determined by Aksu and Kaminski (this volume). The age model for Hole 646B used here is an updated version of the model reported in the Site 646 chapter (Shipboard Scientific Party, 1987a) and is given in Table 1. The ages of magnetostratigraphic units and epoch boundaries used throughout this study are after Berggren et al. (1985), with one exception: the age of the Miocene/Pliocene boundary (4.83 Ma) follows new estimates by Zijderveld et al. (1986).

Core-catcher samples collected aboard ship were processed according to standard laboratory techniques. For Pleistocene samples, foraminifers were picked from the $>63-\mu \mathrm{m}$ fraction, owing to the presence of small calcareous species. Below the barren zone of Site 645 , foraminifers were picked from the $>125-\mu \mathrm{m}$ fraction because of the abundance of very fine sand in the coarse fraction in most samples. If calcareous benthic foraminifers or Bolboforma were found in the $>125-\mu \mathrm{m}$ fraction, the fine fraction was also examined. However, in most samples from Hole $645 \mathrm{E}$ only agglutinated species were present, and the $<125$ $\mu \mathrm{m}$ fraction was barren or contained only unidentifiable fragments. All
pre-Pleistocene samples from Site 646 were picked from the $>125-\mu \mathrm{m}$ fraction.

Pleistocene samples were processed in uniform, $10-\mathrm{cm}^{3}$, wet sediment volumes. Samples with excessive amounts of fine sand were dried and sprinkled into carbon tetrachloride to float off the foraminifers. Pleistocene samples suspended in denatured ethanol and distilled water were split using a wet splitter (Thomas, 1985). Samples having large numbers of foraminifers were split into fractions that contained 300500 specimens for quantitative counts. Pre-Pleistocene samples processed onshore were first dried overnight at $60^{\circ} \mathrm{C}$ and then weighed before sieving to provide data about the absolute abundance of benthic foraminifers. Faunal counts from Holes 645B, 646A, and 647B are given in Tables 2 through 4 , and data from Hole 646B are listed in the Appendix. Foraminifer data from Hole 646B also are available from the senior author in LOTUS 1-2-3 (.WK1) format on 360k MS-DOS floppy disk.

The stratigraphy and paleoecological interpretations of the hemipelagic sequence in the Blue $\mathrm{H}-28$ well are based on analysis of 103 picked slides of foraminifers and associated microfossils from ditch cutting samples. Ages of the sediments in the Blue H-28 well are based on planktonic foraminifer biostratigraphy.

\section{RESULTS}

\section{Site 645 Biostratigraphy}

Fifty-five samples from lithologic Units I and II were examined quantitatively for benthic foraminifers (Table 2). The upper $220 \mathrm{~m}$ of Hole $645 \mathrm{~B}$ contained benthic foraminifer assemblages dominated by calcareous species (Fig. 3). The numerically dominant species in most samples are Stetsonia horvathi, Islandiella teretis, Epistominella takayanagii, Globocassidulina subglobosa, Cassidulina reniforme, Elphidium excavatum forma clavata, Buliminella hensoni, and Bolivina arctica.

The mudline sample at this site contains an assemblage dominated by large, coarsely agglutinated species of Rhabdammina, 
Table 1. Depths below seafloor of biostratigraphic and magnetostratigraphic ages selected to construct the agedepth model for Hole 646B (after Shipboard Scientific Party, 1987).

\begin{tabular}{|c|c|c|}
\hline Name of Datum & $\begin{array}{c}\text { Age } \\
\text { (Ma) }\end{array}$ & $\begin{array}{l}\text { Depth } \\
\text { (mbsf) }\end{array}$ \\
\hline FAD Emiliania huxleyi & 0.247 & $17.8-19.3$ \\
\hline LAD Rhizosolenia curvirostris & 0.26 & $24.1-33.8$ \\
\hline LAD Pseudoemiliania lacunosa & 0.474 & $33.8-37.5$ \\
\hline FAD Globorotalia inflata & a 2.1 & $b_{159.1-159.5}$ \\
\hline LCO Neogloboquadrina atlantica & a 2.3 & $b_{183.3-188.2}$ \\
\hline LAD Discoaster surculis & $>2.4$ & $207.5-208.2$ \\
\hline LCO Reticulofenestra pseudoumbilica & 3.5 & $271.0-272.5$ \\
\hline FAD Globorotalia puncticulata & a 4.16 & $383.0-384.5$ \\
\hline FAD Ceratolithus cristatus & $<4.5$ & $390.0-401.1$ \\
\hline FAD Ceretolithus spp. & $<5.0$ & $468.5-478.1$ \\
\hline FAD Globorotalia margaritae & 5.6 & $b_{506.9-516.5}$ \\
\hline LAD Discoaster quinqueramus & 5.6 & $497.1-506.9$ \\
\hline FAD Amaurolithus primus & 6.6 & $584.2-585.7$ \\
\hline FAD Discoaster quinqueramus & $<8.2$ & $714.0-715.5$ \\
\hline Brunhes/Matuyama & 0.73 & $52.10-73.86$ \\
\hline Top Jaramillo & 0.91 & $76.5-78.10$ \\
\hline Matuyama/Gauss & 2.47 & $190.40-192.60$ \\
\hline Gauss/Gilbert & 3.4 & $292.85-292.95$ \\
\hline Top Nunivak & 4.10 & $347.05-352.85$ \\
\hline Bot Nunivak & 4.24 & $359.45-359.55$ \\
\hline Top $\mathrm{Cl}$ event & 4.57 & $367.84-382.85$ \\
\hline Bot $\mathrm{Cl}$ event & 4.77 & $404.45-429.85$ \\
\hline Top N1 event, Chron 6 & 6.37 & $577.35-577.44$ \\
\hline Bot N1 event, Chron 6 & 6.50 & $578.44-578.55$ \\
\hline Top N1 event, Chron 7 & 6.85 & $637.61-637.63$ \\
\hline Bot N3 event, Chron 7 & 7.28 & $661.98-670.25$ \\
\hline Top N1 event, Chron 9 & 7.90 & $680.14-680.24$ \\
\hline Bot N1 event, Chron 9 & 8.21 & $710.51-710.53$ \\
\hline Top N2 event, Chron 9 & 8.41 & $718.53-718.56$ \\
\hline Bot N1 event, Chron 10 & 8.80 & $733.06-733.08$ \\
\hline Top N1 event, Chron 11 & 8.92 & $733.88-740.33$ \\
\hline
\end{tabular}

${ }^{a}$ Ages of planktonic foraminifer datums are after Weaver and Clement (1986).

${ }^{b}$ Depths are from Aksu and Kaminski (this volume).

Cribrostomoides, Recurvoides, and Saccammina. The calcareous species accompanying this fauna include Islandiella teretis and Stetsonia horvathi.

The upper $40 \mathrm{~m}$ of Hole $645 \mathrm{~B}$ (Cores 105-645B-1X to $-4 \mathrm{X}$ ) contains an assemblage that consists mainly of $I$. teretis, $S$. horvathi, $E$. excavatum, $C$. reniforme, and $B$. hensoni. Miliolid species are locally abundant at about $40 \mathrm{mbsf}$ (Samples 105645B-5X-3, 59-61 cm, and -5X, CC). Floods of Stetsonia horvathi were found between 83 and 121 mbsf (Samples 105-645B$10 \mathrm{X}-2,30-32 \mathrm{~cm}$, and $-14 \mathrm{X}-2,20-22 \mathrm{~cm})$.

Below $\sim 148$ mbsf (Section 105-645B-16X, CC), the assemblage is dominated by Epistominella takayanagii. The interval corresponding to the base of lithologic Unit I and the upper part of Unit II (Cores 105-645B-24X to -32X) is barren of foraminifers, except for minor occurrences of Cassidulina spp. in Cores 105-654B-28X and -29X and E. takayanagii in Core 105645B-31X.

Sediments recovered from Hole 645D belong to lithologic Units II and IIIA. Twenty core-catcher samples were examined from this hole; only two of which (Sections 105-645D-6R, CC and $-13 \mathrm{R}, \mathrm{CC}$ ) contain rare specmens of $I$. teretis, E. excavatum, and G. subglobosa. As the first occurrence (FO) of I. teretis was reported in the mid-Pliocene in the North Atlantic (Murray, 1984), apparently, this Baffin Bay site does not contain a condensed stratigraphy, as suggested by earlier work (Aksu, 1983).

Drilling in Hole 645E penetrated lithologic Units II and III between 301 and 1147 mbsf. A total of 180 samples was examined for foraminifers and associated microfossils. Samples from Unit II and the upper part of lithologic Unit III are barren. Mi- crofossils again were encountered in Subunit IIIB below $\sim 750$ mbsf. These consist mainly of fragments of agglutinated foraminifers. Less commonly, calcareous benthic foraminifers, pyritized diatoms, and specimens of Bolboforma are present. Planktonic foraminifers were found in only two samples. Because of the sparse and fragmentary nature of the assemblages, the microfossil data from this hole were not treated quantitatively.

The presence of Bolboforma metzmacheri at $753.4 \mathrm{mbsf}$ (Section 105-645E-36R, CC) constrains the age of this sample as no younger than nannofossil Zone NN16 (early Pliocene). This species has been reported from the North Atlantic (Murray, 1987b) and the North Sea (King, 1983). In the North Sea, B. metzmacheri occurs together with the dextral form of Neogloboquadrina atlantica and defines King's late Miocene Zone NSP14.

The highest stratigraphic occurrence of coarse agglutinated species occurs at $\sim 770$ mbsf (between Samples 105-645E-38R$3,44-47 \mathrm{~cm}$ and $-38 \mathrm{R}-6,127-129 \mathrm{~cm})$. This event occurs in the lower Pliocene in Hole 646B (see below) and at some DSDP sites in the Norwegian-Greenland Sea (Talwani, Udintsev, et al., 1976; Berggren and Schnitker, 1983). Agglutinated foraminifers are locally abundant to the base of Hole $645 \mathrm{E}$. The assemblages consist mainly of coarse species of Rhizammina, Hyperammina, Cyclammina, Reophax, Lagenammina, Ammodiscus, $\mathrm{Ha}$ plophragmoides, Glomospira, and Trochammina. Less frequently, specimens of Glomospirella, Ammosphaeroidina, and Martinotiella were found, but many samples contain little more than unidentifiable fragments. Miocene assemblages of this type have been reported previously only from DSDP Site 348 in the Norwegian-Greenland Sea (Talwani, Udintsev et al., 1976; Verdenius and Van Hinte, 1983).

The agglutinated assemblages between 792.0 and $844.0 \mathrm{mbsf}$ (from Section 105-645E-40R, CC to Sample 105-645E-46R-3, 95-97 cm) are dominated by coarse astrorhizids and hormosinids, mainly Rhizammina, Lagenammina, and Reophax. Species with finely agglutinated tests become common in Section 105-645E-49R, CC. Samples between 878.2 and $885.3 \mathrm{mbsf}$ (Section 105-645E-49R, CC to Sample 105-645E-51R-1, 41-43 $\mathrm{cm})$ are dominated by finely agglutinated Bathysiphon fragments. Below this interval, the assemblages contain common specimens of Cyclammina cancellata, Recurvoides spp., and Haplophragmoides carinata. Also present is a compressed species of Reticulophragmium similar to a variety described from the Beaufort Sea (Young and McNeil, 1984) that we tentatively identified as $R$. cf. arctica. Near the base of Hole $645 \mathrm{E}$, a change in the composition of the agglutinated assemblage was observed. The assemblage in Section 105-645E-78R, CC is dominated by small species of Ammodiscus and Trochammina.

Calcareous benthic foraminifers also were found between 772.2 and 844.0 mbsf (Samples 105-645E-38R, CC to $-46 \mathrm{R}-3$, $95-97 \mathrm{~cm}$ ). The dominant calcareous species in this interval is Melonis barleeanum. Unilocular species (Lagena, Oolina, and Fissurina) are common, and accessory forms include Globocassidulina subglobosa and species of Nodosaria, Quinqueloculina, and Uvigerina. However, in most samples the preservation of calcareous benthic foraminifers is poor, and only relatively robust specimens are present. Smaller specimens presumably are dissolved. Samples between 861.7 and 974.9 mbsf (105-645E$48 \mathrm{R}-2,84-86 \mathrm{~cm}$ to $-60 \mathrm{R}, \mathrm{CC}$ ) are barren of calcareous foraminifers.

Calcareous foraminifers again were encountered in isolated samples below $\sim 975$ mbsf (Section 105-645E-60R, CC to Sample $105-645 \mathrm{E}-77 \mathrm{R}-1,107-109 \mathrm{~cm})$. In this interval $B$. metzmacheri is absent, and the most common genus is Cibicidoides. The most diverse assemblage occurs in Sample 105-645E-67R-2, $89-91 \mathrm{~cm}$, which contains Oridorsalis umbonatus, Pullenia bulloides, Cibicidoides pachyderma, C. lobatulus, Uvigerina sp. 
Table 2. Abundances of benthic foraminifers identified in samples from Hole 645B.

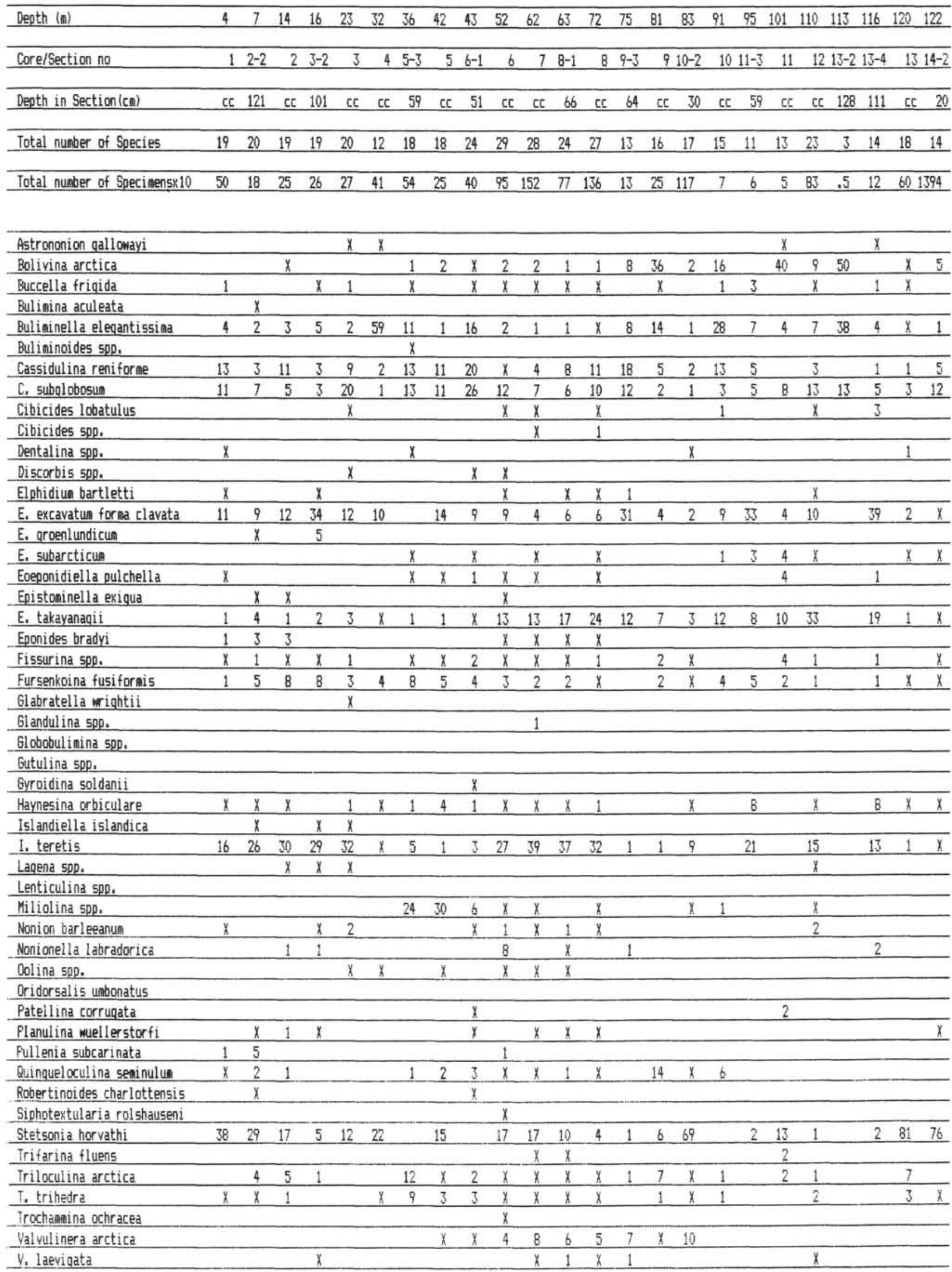


Table 2 (continued).

\begin{tabular}{llllllllllllllllllllllllllllll}
\hline 130 & 139 & 148 & 149 & 158 & 168 & 173 & 177 & 187 & 193 & 197 & 202 & 207 & 208 & 216 & 223 & 226 & 235 & 245 & 254 & 255 & 258 & 265 & 268 & 274 & 283 & 284 & 291 & 293 & 294 \\
\hline
\end{tabular}

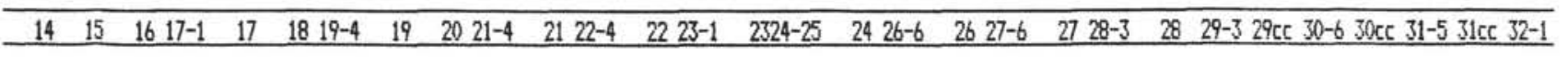

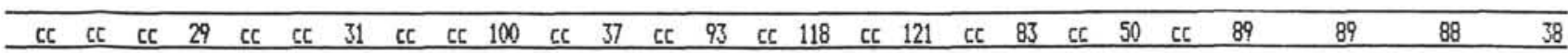
\begin{tabular}{lllllllllllllllllllllllllllllll}
\hline 15 & 9 & 13 & 25 & 15 & 15 & 16 & 2 & 6 & 5 & 5 & 17 & 10 & 14 & 2 & 1 & 1 & 0 & 2 & 2 & 0 & 3 & 0 & 7 & 0 & 0 & 0 & 12 & 10 & 1 \\
\hline
\end{tabular} \begin{tabular}{llllllllllllllllllllllllllllll}
\hline 16 & 26 & 29 & 159 & 303 & 129 & 218 & 3 & 4 & 37 & 1 & 321 & 99 & 7 & .6 & .1 & .1 & 0 & .2 & .2 & 0 & 2 & 0 & 6 & 0 & 0 & 0 & 11 & 5 & .1 \\
\hline
\end{tabular}

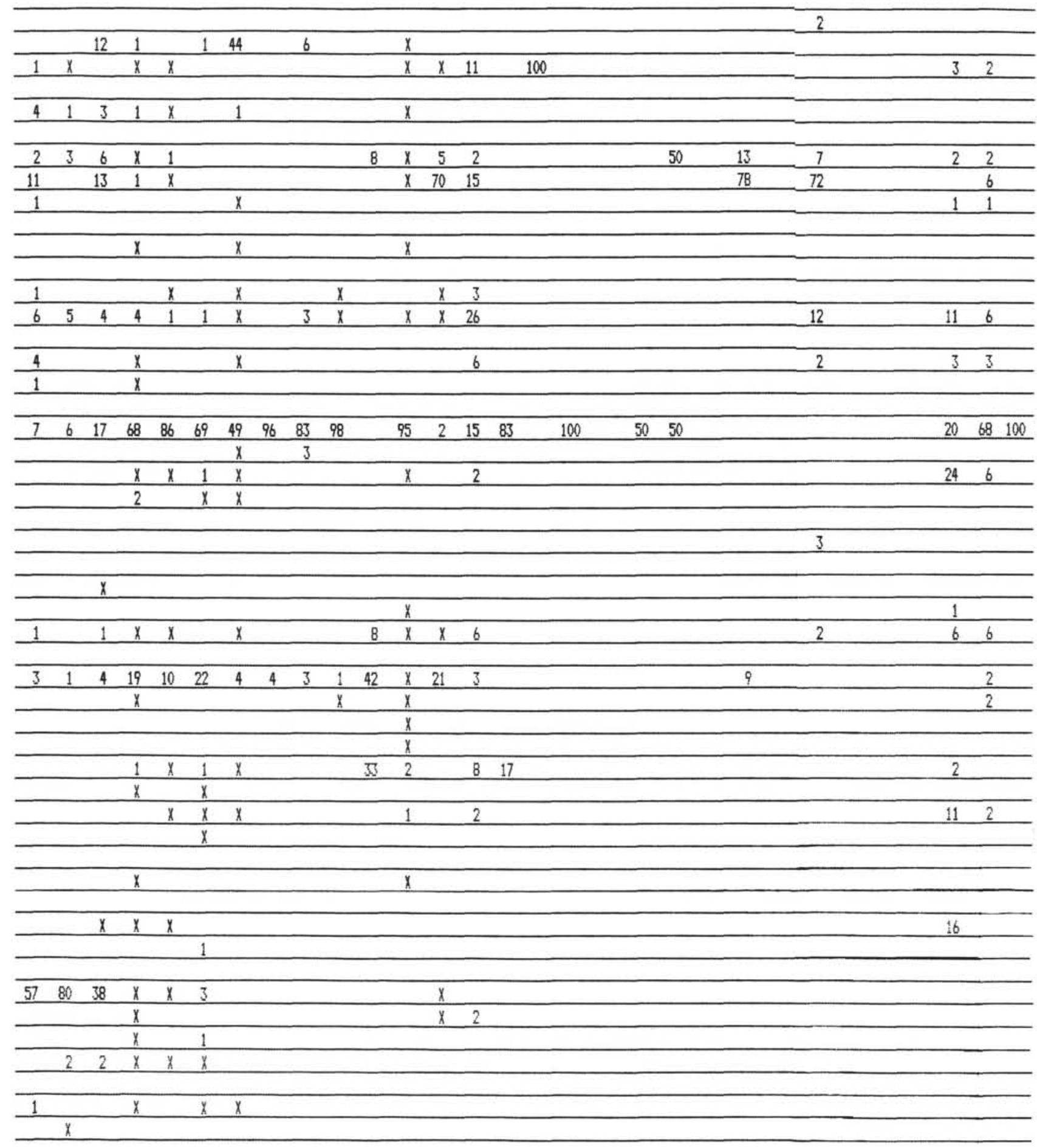


Table 3. Abundances of benthic foraminifers identified in samples from Hole 646B.

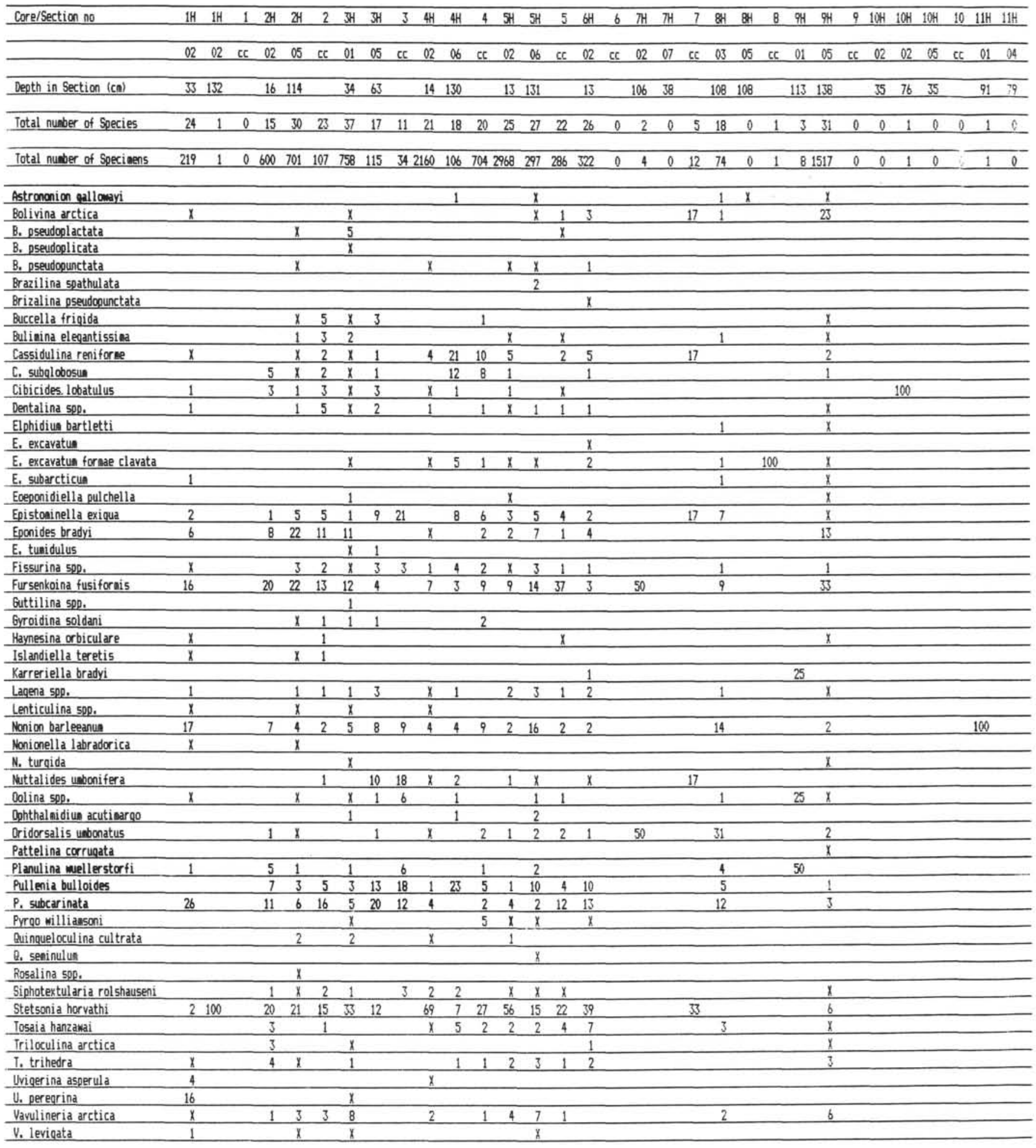

(smooth), and four specimens of Globigerina praebulloides. Although the total range of $G$. praebulloides is from P22 to N18 (Kennett and Srinivasan, 1983), this species is restricted to lower to lower middle Miocene sediments in the North Sea (Zone NSP11 of King, 1983) and lower Miocene sediments on the Labrador Margin (Gradstein and Agterberg, 1982).

\section{Site 646 Biostratigraphy}

A total of 140 samples from Holes 646A and 646B was examined for benthic foraminifers. The abundance data for samples from Hole 646A are given in Table 3, and data from Hole $646 \mathrm{~B}$ are listed in the Appendix. The accumulation rates of ben- 
Table 4. Abundances of benthic foraminifers identified in samples from Hole 647B.

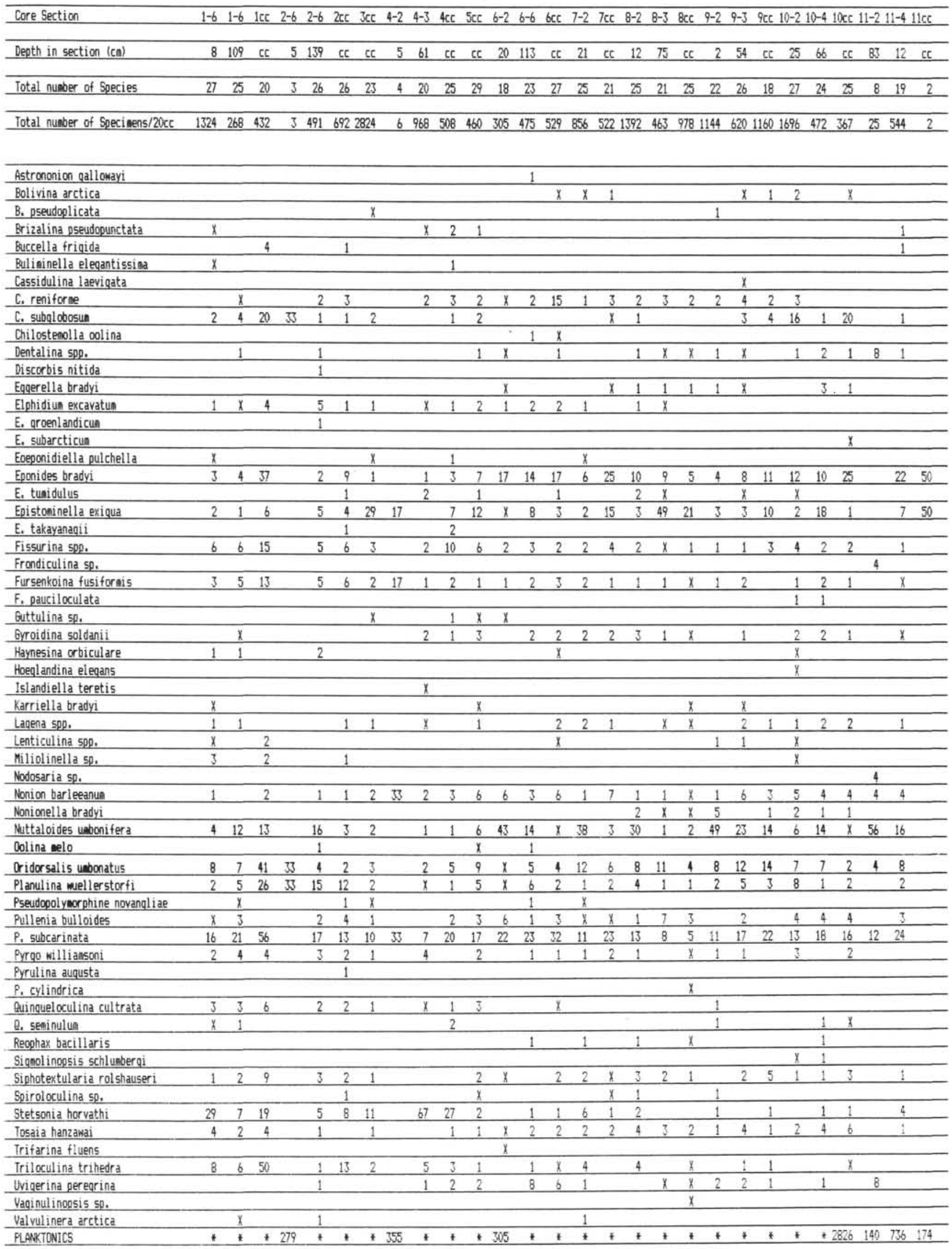




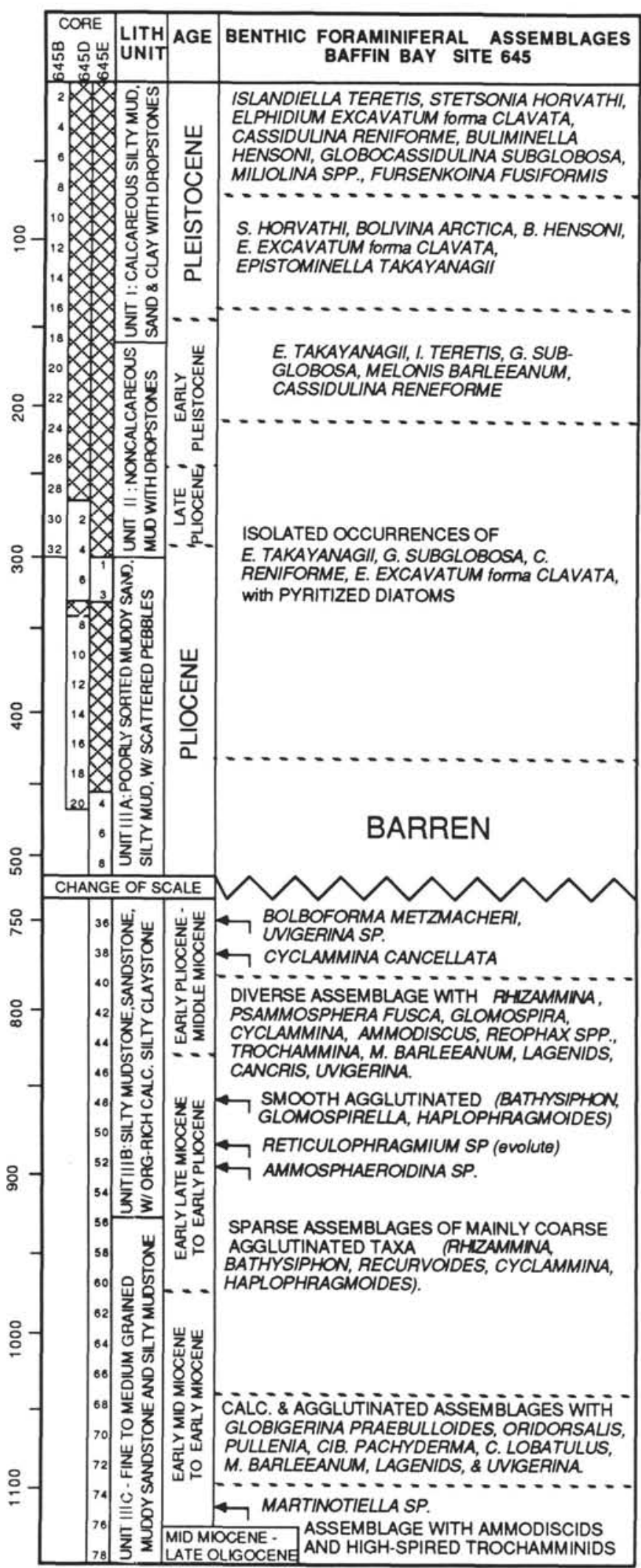

Figure 3. Lithostratigraphy and summary of the benthic foraminifer assemblages and associated microfossils at Site 645, Baffin Bay. The age interpretation of the composite section of Holes 645B, 645D, and 645E is based on the multiple microfossil and paleomagnetic records given in the Site 645 chapter (Shipboard Scientific Party, 1987c). thic foraminifers and the carbonate record from Hole 646B are compared with the regional seismic reflectors in Figure 4. In Hole 646B, major changes in the benthic foraminifer assemblages occur near several of the seismic reflectors identified from shipboard seismic and downhole logging studies. The record of important first and last occurrences in Hole 646B is shown in Figure 5. The composition of each assemblage is discussed in sequence from youngest to oldest.

The upper interval of seismic Unit 1 (Samples 1Q5-646B-lH-2, $33-35 \mathrm{~cm}$ to $-6 \mathrm{H}-2,13-15 \mathrm{~cm}$ ) contains abundant benthic foraminifers dominated by Stetsonia horvathi, with common occurrences of $F$. fusiformis and Pullenia subcarinata. The species Epistominella exigua, Melonis barleeanum, Planulina wuellerstorfi, Cassidulina spp., and Pullenia bulloides are present throughout this interval in lower but significant percentages. The uppermost sample (105-646B-1H-2, 33-35 cm) is co-dominated by Pullenia subcarinata, $M$. barleeanum, $F$. fusiformis, and Uvigerina $\mathrm{sp}$. The assemblages in the upper part of seismic Unit 1 generally display good preservation.

Between Cores 105-646B-6X and -11X, the sediments are essentially barren of foraminifers, except for Sample 105-646B$9 \mathrm{H}-5,138-140 \mathrm{~cm}$, which contains abundant Fursenkoina fusiformis and Bolivina arctica, and Sample 105-646B-8H-3, 108$110 \mathrm{~cm}$, which contains a few specimens of Oridorsalis (Table 3). A major turnover in the benthic assemblage occurs near the base of seismic Unit 1, which overlies the sediment drift. Between 206 and 236 mbsf (Samples 105-646B-23X-5, 122-124 cm to $-25 \mathrm{X}, \mathrm{CC}$ ), the last occurrence (LO) of Laticarinina pauperata, Hoeglundina elegans, and Sigmoilopsis schlumbergeri was encountered. In the Norwegian-Greenland Sea, Laticarinina and Hoeglundina also disappear before the onset of glacial conditions (Talwani, Udintsev, et al., 1976). At Rockall Margin Site $552 \mathrm{~A}$, the LO of Laticarinina was recorded in the late Pliocene by Murray (1984). The lower part of seismic Unit 1 contains a low abundance Melonis barleeanum assemblage. Assemblages containing common $M$. barleeanum are typical of glacial sediments in lower bathyal DSDP sites in the northern North Atlantic (Murray, 1984) and in the Norwegian-Greenland Sea (Talwani, Udintsev, et al., 1976).

Within the sediment drift (seismic Unit 2), the abundance of benthic foraminifers is still low, and the assemblage is numerically dominated by Melonis barleeanum, Pullenia bulloides, $\mathrm{Ci}$ bicidoides spp., and unilocular forms (Lagena, Oolina, and Fissurina) and entosolenians. This assemblage also contains a greater proportion of species that are typical of modern North Atlantic Deep Water (NADW) (Oridorsalis spp., Planulina wuellerstorfi, Globocassidulina subglobosa) than assemblages in other seismic units. The first occurrence of Islandiella teretis was found in Sample 105-646B-39X-2, 15-17 cm. This species first appears in the upper Pliocene of Rockall Margin sites (Murray, 1984).

The base of the drift sequence was placed at 377 mbsf from the seismic record. A major benthic faunal break occurs between 387.4 and 391.0 mbsf (between Samples 105-646B-41X-5, $10-12 \mathrm{~cm}$ and $-41 \mathrm{X}, \mathrm{CC})$. Below the seismic reflector delineating the base of the drift, the upper Miocene to basal Pliocene benthic foraminifer assemblages of seismic Unit 3 are numerically dominated by coarse Rhizammina and associated agglutinated taxa (Cyclammina pusilla, Haplophragmoides, Psammosphaera, Recurvoides, Reophax, Trochammina, Lagenammina, and Ammobaculites). Calcareous benthic foraminifers are numerically subordinate and are represented by Oridorsalis, Melonis barleeanum, M. pompilioides, Pullenia bulloides, and Cibicidoides spp. Near the middle of seismic Unit 3 (between Sections 105-646B-47X, CC and -53, CC), Nuttallides umbonifera occurs sporadically and in low numbers. There is a smaller percentage of unilocular species in seismic Unit 3 than in the overlying unit. 


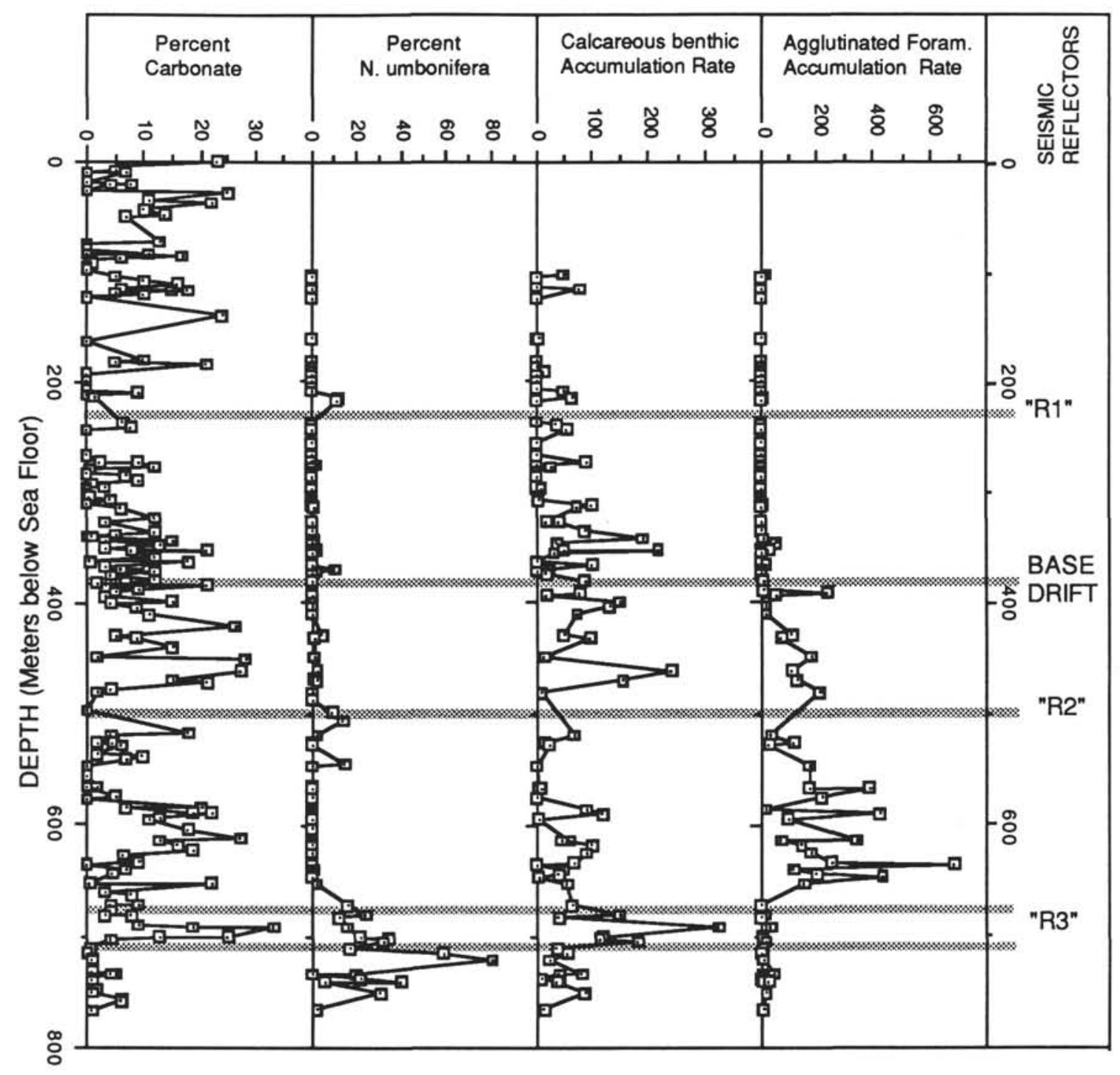

Figure 4. Accumulation rates of benthic foraminifers, calcium carbonate content, and percentages of Nuttallides umbonifera in Hole 646B. Carbonate data are from the Site 646 chapter, supplemented by additional analyses of core-catcher samples. Also shown are the positions of important regional seismic reflectors.

The upper reflector of the R3 couplet originally was placed at 680 mbsf (Shipboard Scientific Party, 1987a). Between 671 and $651 \mathrm{mbsf}$, another distinct change in the benthic foraminifer assemblage occurs: coarse agglutinated taxa become sporadic and rare downhole. The calcareous assemblages within the seismic couplet (Cores 105-646B-72X and -73X) are transitional between assemblages from seismic Units 3 and 4 . In the six samples examined from Cores 105-646B-72X and -73X, the proportion of $N$. umbonifera is approximately equal to the proportion of NADW species. The calcareous species Planulina renzi was found in Samples 646B-73X-2, 58-60 cm and -73X, CC. In the Gulf of Mexico, the LO of this species was reported in Zone N17 (Van Morkhoven et al., 1986).

In seismic Unit 4 (710-766 mbsf), the benthic foraminifer assemblage is dominated by Nuttallides umbonifera (Fig. 4). The abundance of this species was correlated positively with the degree of undersaturation of bottom waters with respect to calcium carbonate (Bremer and Lohmann, 1982). Characteristic accessory species in this assemblage are agglutinated foraminifers having smooth, finely finished tests, such as Bathysiphon,
Ammodiscus, and Glomospira. Isolated specimens of Cyclammina cancellata also occur near the base of Hole 646B, but its LO is probably not isochronous with its LO on the Labrador Margin or in Hole 645E.

\section{Site 647 Biostratigraphy}

A total of 28 samples from lithologic Unit 1 of Hole 647A was examined for benthic foraminifers, and total numbers of specimens range from 3 to 2824 per $10 \mathrm{~cm}^{3}$. Assemblages in a given sample in Cores $105-647 \mathrm{~A}-1 \mathrm{H}$ to $-5 \mathrm{H}$ are highly variable and may be dominated by any of the following species: $S$. horvathi, $P$. subcarinata, N. umbonifera, Oridorsalis, or E. exigua. Common accessory species include $M$. barleeanum, $P$. wuellerstorfi, Fissurina spp., Triloculina trihedra, and Eponides bradyi (Table 4). The high variability of assemblages may be due to low density of sampling and to Milankovitch-forcing functions in this data set.

Samples 105-647A-6H-2, 20-22 cm and -6H-6, 113-115 cm are dominated by $N$. umbonifera and $P$. subcarinata, with commom $E$. bradyi. The FO of Uvigerina was observed in Sample 


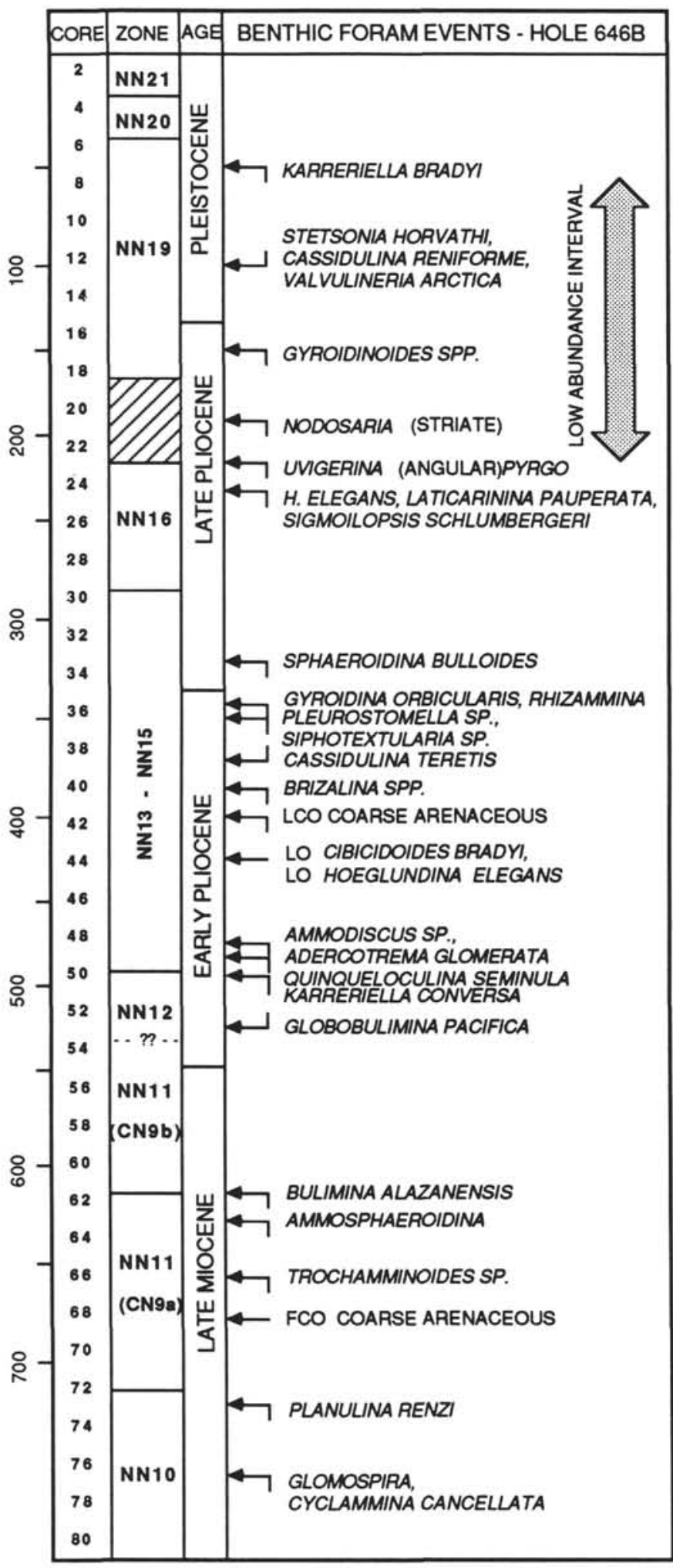

Figure 5. Plotted record of first and last occurrences of benthic foraminifers in Site 646 vs. shipboard nannofossil stratigraphy (Shipboard Scientific Party, 1987a).

105-647A-6H-6, 20-22 cm. Section 105-647A-6H, CC marks the FO of $B$. arctica and is the only sample containing high percentages of Cassidulina reniforme.

The Pliocene/Pleistocene boundary was placed at approximately $72 \mathrm{mbsf}$, or within Core 105-647A-8H, based on interpo- lation using the age-depth model for this site (Shipboard Scientific Party, 1987b). Cores $105-647 \mathrm{~A}-8 \mathrm{H}$ to $-10 \mathrm{H}$ contain planktonic oozes having high numbers of benthic foraminifers. These assemblages are mostly dominated by $N$. umbonifera and $P$. subcarinata, with subdominant $G$. subglobosa and Oridorsalis. One sample $(105-647 \mathrm{~A}-8 \mathrm{H}-3,75-77 \mathrm{~cm})$ is dominated by $E$. exigua.

Two of the three samples examined from Core 105-647A-11H were almost barren, but Sample 105-647A-11H-4, $12-14 \mathrm{~cm}$, contained an abundant assemblage dominated by $P$. subcarinata and E. bradyi. The base of lithologic Unit I of Site 647 has an estimated age of $2.5 \mathrm{Ma}$, based on the planktonic microfossil and magnetostratigraphic evidence. A hiatus of at least 3 m.y. duration separates the upper Pliocene from the underlying upper Miocene.

\section{Texaco Blue H-28 Well}

The Neogene biostratigraphic record of the Texaco Blue-H28 well displays a fourfold division, based on planktonic foraminifer stratigraphy (Fig. 6). The foraminifer assemblages are discussed from from oldest to youngest.

Middle Miocene sediments containing Sphaeroidinella seminulina and Catapsydrax dissimilis occur between 3810 and 3640 mbsf and immediately overlie lower Oligocene and older sediments. The middle Miocene benthic assemblage is rich in agglutinated species, including Bathysiphon, Rhizammina, Saccammina, Cystammina, Cyclammina placenta, Cyclammina pusilla, Cyclammina orbicularis, Cribrostomoides subglobosus, Karreriella conversa, and Sigmoilopsis schlumbergeri. This assemblage is remarkably similar to the assemblage from the upper Miocene to lower Pliocene seismic Unit 3 of Hole 646B. Calcareous foraminifers that testify to a deep (at least middle to lower bathyal) environment are Laticarinina, Melonis pompilioides, and Cibicidoides wuellerstorfi.

The upper Miocene (N16-N18) occurs between 3640 and 3160 mbsf. This interval contains the last occurrences of Sigmoilopsis schlumbergeri, Neogloboquadrina humerosa-atlantica, $N$. acostaensis, $N$. continuosa, Globoquadrina dehiscens, and the $G$. menardii group. A diverse agglutinated assemblage similar to the one mentioned above occurs between 3200 and 3500 mbsf.

The upper Pliocene/lower Pliocene boundary in this well was originally determined by the last occurrences of Neogloboquadrina atlantica and Globorotalia hirsuta near 2550 mbsf. However, Aksu and Kaminski (this volume) report the last appearance datum (LAD) of $N$. atlantica at $\sim 2.4 \mathrm{Ma}$ in the Labrador Sea. Therefore, the LO of this species in exploration wells along the Labrador Margin may be a useful indicator of the preglacial Pliocene. Another useful LO in this well is G. puncticulata, which has a LAD at $3.8 \mathrm{Ma}$ in Hole 646B (Aksu and Kaminski, this volume). Through much of the Pliocene, the benthic foraminifers are represented by calcareous taxa such as Elphidium, Gyroidina, Cassidulina, Uvigerina, and Laticarinina. However, an assemblage rich in coarse agglutinated species similar to those mentioned above occurs at 2600 mbsf.

\section{DISCUSSION}

\section{Paleoecology of Benthic Foraminifers}

\section{Agglutinated Assemblages}

Neogene agglutinated foraminifer assemblages are known from silled high-latitude basins, such as the Norwegian-Greenland Sea and Baffin Bay, but until now, Neogene agglutinated assemblages have not been reported from any DSDP site in the deep North Atlantic. Agglutinated assemblages are present in Paleogene sediments of the Labrador Sea (Gradstein and Berggren, 1981) as well as in the modern North Atlantic (Schroder, 
TEXACO BLUE H-25 WELL

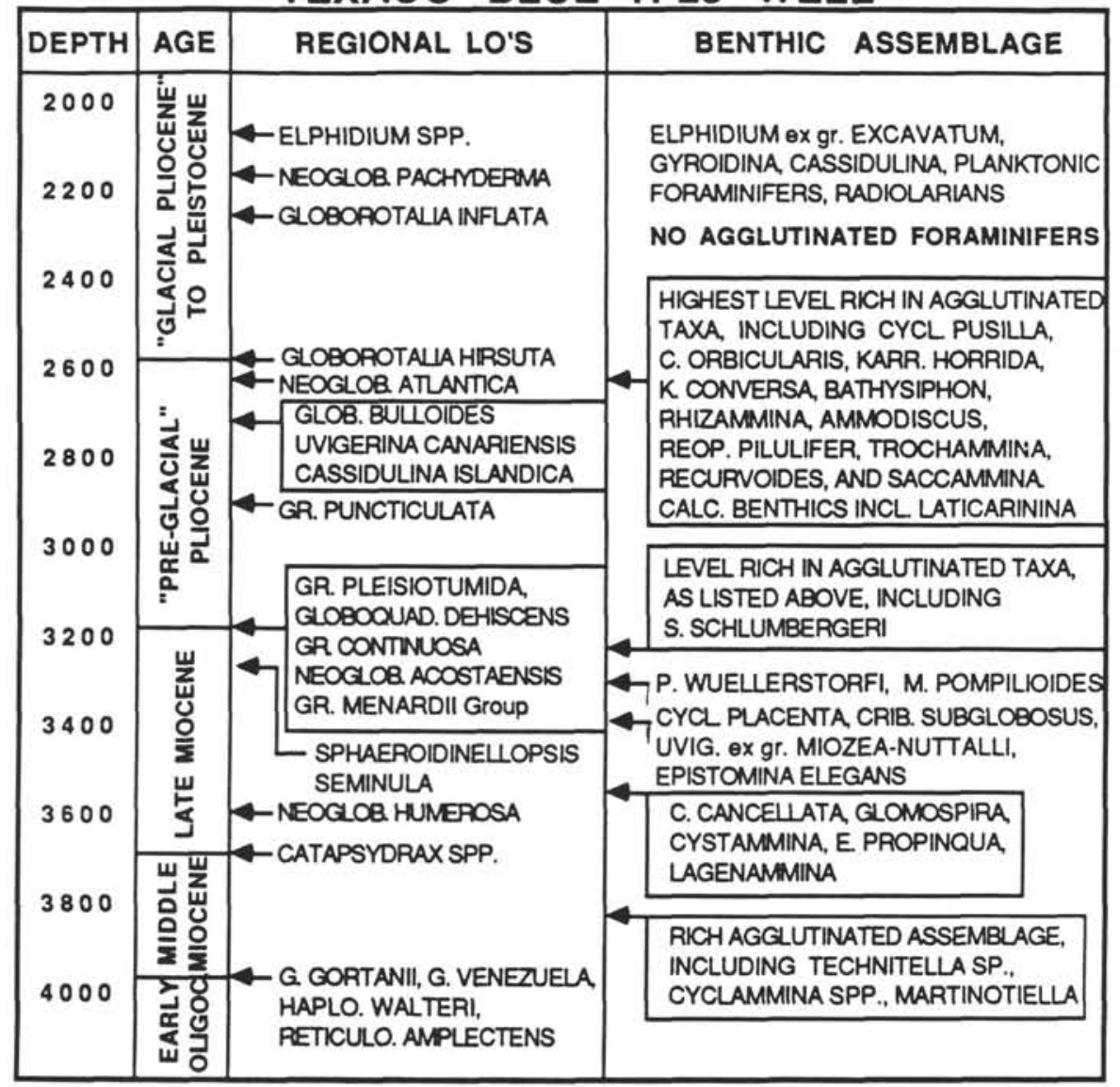

Figure 6. Biostratigraphic record of the Texaco Blue H-28 well, Labrador Margin.

1986), but are usually not preserved in Neogene sediments. Until now, the only link in time between these occurrences has been the Pliocene agglutinated assemblages in the Texaco Blue H-28 well on the Labrador Margin. Therefore, the microfossil record from Site 646 is unique in containing well-preserved agglutinated foraminifers.

The presence of agglutinated foraminifers in Cenozoic sediments is usually associated with sediment parameters that allow the preservation of organic matter. The ecology of early Cenozoic "flysch-type" agglutinated assemblages was discussed by Gradstein and Berggren (1981) and Miller et al. (1982). These authors noted the occurrence of these assemblages in areas of rapid sedimentation and in sedimentary basins containing corrosive bottom water. The set of environmental conditions associated with flysch-type assemblages has become known as the "old bottom-water model." The disappearance of these assemblages from the deep Labrador Sea near the Eocene/Oligocene boundary was correlated with the onset of vigorous deep circulation and more oxygenated conditions (Miller et al., 1982; Miller and Tucholke, 1983). After this event in the North Atlantic, agglutinated assemblages persisted only in the high-latitude basins. In accordance with the old bottom-water model, for agglutinated assemblages to be preserved in the upper Miocene to lower Pliocene of the Labrador Sea, sediment parameters or bottom-water properties must have surpassed a certain threshhold. But which parameter or combination of parameters is unique to Site $646 ?$

A compilation of sediment properties (Table 5) reveals that Site 646 has little in common with most Atlantic sites. With the exception of Site 114 on the east flank of the Reykjanes Ridge, lower Pliocene sediments in the eastern Altlantic are nannofossil oozes having high calcium carbonate contents. Drilling at DSDP Hole 114 penetrated drift sediments having a carbonate content of about $26 \%$ and a higher sedimentation rate than in Hole $646 \mathrm{~B}$, but no agglutinated assemblages were recovered.

The Miocene to early Pliocene deep water in the NorwegianGreenland Sea and Arctic Ocean apparently was corrosive, as deep sites have carbonate contents of less than 1\% (Talwani, Udintsev, et al., 1976). Agglutinated foraminifer assemblages are present in pre-glacial Pliocene sediments of DSDP Hole 344 on the Knipovich Ridge and Hole 345 in the Lofoten Basin. In Cores 26 through 33 of Hole 344, the generic composition of the foraminifer assemblage is remarkably similar to the assemblages in the Eirik Ridge. The assemblage consists mainly of Bathysiphon, Haplophragmoides, Reophax, Hormosina, and Saccammina, but at some levels Melonis barleeanum and I. teretis occur together with the planktonic species Neogloboquadrina atlantica. The LO of coarse agglutinated species is associated with the onset of ice rafting in Hole 345. The pre-glacial assemblage at this site consists of Cyclammina, Haplophragmoides, and Martinotiella, and is more diverse than the underlying Miocene assemblage (Talwani, Udintsev, et al., 1976).

We speculate that the coarse agglutinated assemblages at Site 646 indicate the presence of corrosive bottom water derived from the Norwegian-Greenland Sea. Drilling at Hole 113 in the Labrador Sea recovered a thick sequence of turbidite sediments in a local topographic depression. Calcium carbonate content is 
Table 5. Compilation of late Miocene environmental parameters from DSDP holes in the North Atlantic.

\begin{tabular}{|c|c|c|c|c|c|c|c|c|c|c|c|c|c|}
\hline Location & Site & Cores & Latitude & $\begin{array}{l}\text { Depth } \\
\text { (mbsf) }\end{array}$ & WBD & TOC & $\begin{array}{c}\text { Carbon } \\
(\%)\end{array}$ & $\begin{array}{l}\text { Clay } \\
(\%)\end{array}$ & $\begin{array}{l}\text { Sand } \\
(\%)\end{array}$ & Silica? & Drift? & $\begin{array}{l}\text { Sed rate } \\
(\mathrm{m} / \mathrm{m} . \mathrm{y} .)\end{array}$ & Aggl? \\
\hline \multirow[t]{3}{*}{ Labrador Sea } & 646 & $26-53$ & $58^{\circ} 13^{\prime} \mathrm{N}$ & 3455 & 2 & 0.4 & $0-20$ & 90 & 5 & No & Yes & 90 & Yes \\
\hline & $112 \mathrm{~A}$ & 5 & $54^{\circ} 47^{\prime} \mathrm{N}$ & 3615 & 1.7 & NA & NA & NA & NA & No & No & 20 & No \\
\hline & $111 \mathrm{~A}$ & $5-6$ & $50^{\circ} 25^{\prime} \mathrm{N}$ & 1797 & 1.7 & 0.1 & 72 & 21 & 54 & No & No & 0.4 & No \\
\hline \multirow[t]{9}{*}{ East North Atlantic } & 114 & $4-6$ & $59^{\circ} 56^{\prime} \mathrm{N}$ & 1927 & 1.6 & 0.1 & 26 & 23 & 20 & Yes & Yes & 120 & No \\
\hline & 116 & 2 & $57^{\circ} 30^{\prime} \mathrm{N}$ & 1151 & 1.7 & 0.1 & 90 & 44 & 5 & Yes & No & 30 & No \\
\hline & 610 & $8-10$ & $53^{\circ} 13^{\prime} \mathrm{N}$ & 2417 & 1.8 & NA & 95 & NA & NA & No & Yes & 51 & No \\
\hline & 609 & $26-31$ & $49^{\circ} 52^{\prime} \mathrm{N}$ & 3883 & 1.8 & NA & 90 & NA & NA & No & No & 89 & No \\
\hline & 608 & $13-15$ & $42^{\circ} 50^{\prime} \mathrm{N}$ & 3541 & 1.7 & NA & 95 & $\mathrm{NA}$ & NA & No & No & 19 & No \\
\hline & $552 \mathrm{~A}$ & $14-23$ & $56^{\circ} 03^{\prime} \mathrm{N}$ & 2311 & 1.7 & 0.1 & 93 & 80 & 5 & Yes & Yes & 25 & No \\
\hline & $553 \mathrm{~A}$ & 3 & $56^{\circ} 06^{\prime} \mathrm{N}$ & 2339 & 1.7 & 0.1 & 92 & 90 & 5 & Yes & Yes & 30 & No \\
\hline & 554 & $5-6$ & $56^{\circ} 18^{\prime} \mathrm{N}$ & 2584 & 1.7 & 0.1 & 97 & 85 & 10 & Yes & No & 7 & No \\
\hline & 555 & 3 & $56^{\circ} 34^{\prime} \mathrm{N}$ & 1669 & 1.8 & 0.1 & 94 & 70 & 15 & Yes & No & 16 & No \\
\hline \multirow[t]{2}{*}{ Greenland Sea Ridge } & 407 & $8-14$ & $63^{\circ} 56^{\prime} \mathrm{N}$ & 2492 & 1.6 & NA & 85 & NA & NA & No & No & 45 & No \\
\hline & 408 & $11-13$ & $63^{\circ} 23^{\prime} \mathrm{N}$ & 1634 & 1.6 & NA & 85 & NA & NA & Yes & No & 35 & No \\
\hline & 344 & $26-33$ & $76^{\circ} 09^{\prime} \mathrm{N}$ & 2201 & 2.1 & 0.8 & 1 & 45 & 5 & No & No & 76 & Yes \\
\hline & 345 & $5, \mathrm{CC}-6$ & $69^{\circ} 50^{\prime} \mathrm{N}$ & 3216 & 1.7 & 0.4 & 1 & NA & NA & No & No & NA & Yes \\
\hline & 348 & $6-7$ & $68^{\circ} 30^{\prime} \mathrm{N}$ & 1777 & 1.4 & 0.3 & 1 & 50 & 5 & Yes & No & 22 & No \\
\hline
\end{tabular}

WBD $=$ wet-bulk density; TOC = total organic carbon; Silica? = presence of biogeneic silica; Drift $?=$ site location on sediment drift; Aggl $?=$ presence of agglutinated foraminifers.

low, and sedimentation rate is higher than in Hole 646B. However, Hole 113 is not in the pathway of Denmark Straits Overflow Water.

The trophic structure of the agglutinated foraminifer assemblage is another clue to the nature of the depositional environment at Site 646. The assemblage in seismic Unit 3 is strongly dominated by coarsely agglutinated specimens of Rhizammina, which is an epibenthic suspension-feeder (Jones and Charnock, 1985). Benthic communities dominated by suspension-feeders are rare in the deep sea (Jumars and Gallagher, 1982) because the ratio of suspension-feeders to deposit-feeders normally declines with depth and distance from shore (Levinton, 1982). Suspension-feeding communities in the deep sea have been found only near hydrothermal vents (Lonsdale, 1977) or in areas where there is a lateral advection of food particles (L. Mullineaux, pers. comm., 1987). In Alvin dives, H. Sanders (pers. comm., 1987) observed concentrations of suspension-feeding animals on top of local topographic elevations, whereas local depressions were occupied by deposit-feeders. In the modern North Atlantic, there is an increased proportion of the coarse tubular agglutinated species beneath the Western Boundary Undercurrent (WBUC) (Schroder, 1986). Thus, a Rhizammina community presumably requires moving bottom currents to supply it with food. However, the genus is sessile and probably cannot escape the effects of strong bottom currents. The change from agglutinated assemblages below the sediment drift to calcareous assemblages in the drift may reflect higher bottom current intensities, which may have inhibited Rhizammina and resulted in increased ventilation of the deep environment.

In contrast, the assemblage in seismic Unit 4 of Site 646 contains a greater proportion of species with finely agglutinated tests (Table 6). Species restricted to this assemblage, Ammodiscus and Glomospira, were identified as epifaunal detrital feeders (Jones and Charnock, 1985) and presumably have a low tolerance for disturbed environments. In the modern North Atlantic, these organisms are present in greater proportion in environments that are relatively undisturbed by bottom currents (Kaminski, 1985).

The agglutinated assemblages from the Texaco Blue $\mathrm{H}-28$ well are remarkably similar to those from seismic Unit 3 in Hole 646B. Each species we found in the Pliocene of the Blue H-28 well also occurs in Hole 646B, and specimens of Rhizammina
Table 6. Summary of important benthic foraminifer species and species groups in Hole 646B.

\begin{tabular}{lcccc}
\hline \multicolumn{1}{c}{ Taxa } & $\begin{array}{c}\text { Seismic } \\
\text { Unit 2 }\end{array}$ & $\begin{array}{c}\text { Seismic } \\
\text { Unit 3 }\end{array}$ & $\begin{array}{c}\text { Seismic } \\
\text { Unit 3/4 }\end{array}$ & $\begin{array}{c}\text { Seismic } \\
\text { Unit 4 }\end{array}$ \\
\hline Melonis spp. (\%) & $18.1 \%$ & $5.2 \%$ & $12.1 \%$ & $3.2 \%$ \\
Smooth agglutinated spp. & 0 & 0 & 0.7 & 7.0 \\
Coarse agglutinated spp. & 7.0 & 65.6 & 8.0 & 13.9 \\
Nuttallides umbonifera & 0.9 & 0.9 & 18.4 & 25.0 \\
a NADW species & 10.3 & 4.9 & 19.4 & 11.5 \\
Other species & 63.7 & 23.3 & 41.3 & 39.4 \\
Number of samples & 32 & 40 & 6 & 12 \\
\hline
\end{tabular}

- Seismic Unit 3/4 samples are from the calcareous interval within the reflector R3 couplet.

a Values for NADW species are derived from the combined abundances of $P$. wuellerstorfi, Oridorsalis, G. subglobsa, and E. exigua.

Note: Numbers represent the mean values of census data from each seismic unit.

are about the same size. This well site is located under the current axis of the Western Boundary Undercurrent. The predominant lithology is hemipelagic clay, and sedimentation rates increase dramatically from $100 \mathrm{~m} / \mathrm{m}$.y. in the late Miocene to $\sim 300 \mathrm{~m} / \mathrm{m}$.y. in the Pliocene and Pleistocene. In the Miocene interval of the well, the occurrence of agglutinated taxa is fairly continuous, but in the Pliocene, agglutinated taxa cluster at discrete levels. We tentatively interpreted the preservation of this assemblage as an indication of periods of slower deposition. We postulate that the highest level with agglutinated taxa at $2610 \mathrm{~m}$ may coincide with an increase in local WBUC circulation near the onset of ice rafting at $2.5 \mathrm{Ma}$. However, the exact chronology cannot be resolved.

One of the key environmental factors controlling the presence of Neogene flysch-type faunas in the high-latitude North Atlantic basins appears to be the local formation of bottom waters. The change from a predominantly agglutinated assemblage to a calcareous assemblage in the Pliocene is associated with the onset of drift sedimentation at Site 646. This change may reflect a change in deep-water properties and current intensities, which ultimately may be linked to the initiation of convective overturn of deep waters and the onset of vigorous circulation in the Norwegian-Greenland Sea. Agglutinated assemblages are present in 
the Miocene to lower Pliocene of Norwegian-Greenland Sea sites, but the modern microfossil chronology of the area does not provide the resolution to determine if the $\mathrm{LO}$ of flysch-type taxa is isochronous in both regions. However, we speculate that the events are closely linked. Agglutinated assemblages persisted to younger stratigraphic levels in the deep Arctic Ocean. In some of the longer cores obtained by the Arctic Ocean CESAR Expedition, the Pliocene/Pleistocene boundary is marked by the last common occurrence (LCO) of agglutinated foraminifers. This event appears to be correlated with the onset of perennial sea-ice formation in the Arctic Ocean (Scott et al., 1987). The formation of dense waters through brine release from seaice formation apparently ventilates the deep basins. Therefore, the observed pattern of the LCO of flysch-type assemblages in the high-latitude North Atlantic basins appears to be consistent with the old bottom-water model of Gradstein and Berggren. We believe that the initiation of significant bottom-water formation by thermohaline processes resulted in the loss of agglutinated foraminifers from the high-latitude fossil record.

\section{Pre-Glacial Pliocene Assemblage}

The Pliocene assemblage above the LCO of agglutinated species in Hole 646B is unlike assemblages from the eastern Atlantic described by Murray (1984). The dominant species of the drift sediments are Melonis barleeanum, Pullenia bulloides, $\mathrm{Ci}$ bicidoides spp., and unilocular species. Islandiella teretis and Uvigerina peregrina are sometimes common. The proportion of species that are typical of modern NADW, such as $E$. exigua, $P$. wuellerstorfi, and G. subglobosa, is small in comparison with pre-glacial Piocene assemblages in eastern Atlantic sites.

Melonis barleeanum ( $=M$. zaandamae $)$ is most common in high latitudes. It is the dominant calcareous species in the Miocene of Baffin Bay and in the rare intervals of calcareous sediments in the Norwegian-Greenland Sea. In the pre- glacial Pliocene of DSDP Site 343 , this species occurs with $P$. bulloides (Talwani, Udintsev, et al., 1976).

The change from a pre-glacial Pliocene assemblage to a glacial assemblage is usually marked by a clustering of first and last occurrences, and species that are typical of modern low latitudes are replaced by boreal forms. This turnover was diachronous with latitude in the North Atlantic, and not suprisingly, began earlier at Site 646 than in the eastern Atlantic. For example, Pleurostomella disappeared in the early Pliocene at Site 646, but persisted until the Pliocene/Pleistocene boundary at Feni Ridge Site 610 (Thomas, 1987). In the eastern Atlantic, Pliocene peak benthic foraminifer turnover occured between 3.0 and 2.5 Ma at King's Trough Site 608, and between 3.3 and 2.4 $\mathrm{Ma}$ at shallower Site 610 (Thomas, 1987). At $1.5 \mathrm{Ma}$, N. umbonifera decreased in abundance in Site 608 , signaling a retreat of corrosive water. In Hole $647 \mathrm{~A}$, this event occurs at about 47 mbsf, or $1.0 \mathrm{Ma}$.

\section{Glacial Assemblages}

At the sampling resolution undertaken here, biostratigraphic correlation of Pleistocene age assemblages among Leg 105 sites was not possible. Baffin Bay is an isolated basin with assemblages unlike those at any depth in the Atlantic. None of the Pleistocene biostratigraphic events recorded in our data have chronostratigraphic utility. However, the paleoecology of benthic assemblages determined at each site can be interpreted, based on correlations with site-survey piston cores (Scott et al., this volume).

The Baffin Bay piston core recovered a 12-m section of sediment covering a time span of about 30-50 k.y. Low numbers of foraminifers are associated with carbonate-rich turbidite layers, and higher abundances of foraminifers occur in the interbedded clays. In the piston core, Stetsonia horvathi is the dominant taxon throughout, with Buliminella hensoni as a secondary species. Elphidium, Cassidulina, and miliolid species are present in low numbers. The Stetsonia assemblage in the piston core is almost identical to that present in the today's Arctic Ocean below a depth of $\sim 900 \mathrm{~m}$ (Lagoe, 1977). However, one should be careful when interpreting assemblages with abundant Stetsonia as indicators of Arctic deep-water infuence. The shallow sill depth between Baffin Bay and the Arctic Ocean makes the mixing of deep Arctic and Baffin Bay waters unlikely. In Hole 645B, Stetsonia was found in Cores $105-645 \mathrm{~B}-1 \mathrm{X}$ to $-8 \mathrm{X}$, which suggests similar hydrographic conditions represented by the upper $80-90$ $\mathrm{m}$ of Hole $645 \mathrm{~B}$ to the present day. Epistominella takayanagii becomes the dominant taxon in samples from Cores 105-645B$8 \mathrm{X}$ to $-23 \mathrm{X}$, which suggests that paleoenvironmental conditions must have been different below Core 105-645B-8X. Although $E$. takayanagii is present in the piston core, it never dominates. The dominance of this taxon between Cores 105-645B-8X and $23 \mathrm{X}$ is unusual, as there are no known recent assemblages dominated by $E$. takayanagii. This species has been observed in low numbers in today's cold Gaspe Current in Chaleur Bay, New Brunswick, but not in deeper water. The only other reported occurrence of an E. takayanagii assemblage is in the Pleistocene of Sites 612 and 613 off New Jersey (Scott, 1987). In this area the species occurred over a wide depth range $(2200-4400 \mathrm{~m})$ in an otherwise glacial assemblage.

At Site 646 , we recovered a short $(5 \mathrm{~m})$ piston core that only penetrated to the top of isotope stage 5 (see Scott et al., this volume). Interglacial assemblages in this core contain $E$. exigua and $E$. bradyi as dominant forms, and glacial assemblages consist of $P$. subcarinata, Triloculina spp., Fursenkoina fusiformis, and $S$. horvathi. Species of Uvigerina occur rarely in glacial sections. Both of these assemblages were observed in Cores 105$646 \mathrm{~A}-1 \mathrm{H}$ to $-6 \mathrm{H}$. In particular, the presence of $E$. exigua suggests that the WBUC was present in interglacials during much of the Pleistocene at this water depth.

At Site 647, the site-survey core provided us with a high-resolution record back to isotope stage $7 \mathrm{c}$. The faunal diversity at Site 647 was the highest of the three sites. Interglacial assemblages are characterized by $N$. umbonifera and $E$. exigua. These occur together with Triloculina sp. and $S$. horvathi in the upper part of stage 5. Glacial assemblages contain lower numbers of individuals and high percentages of Uvigerina spp., F. fusiformis, Triloculina spp., and P. subcarinata. This type of assemblage also was observed in low-resolution samples from Hole $647 \mathrm{~A}$ in Cores $105-647 \mathrm{~A}-1 \mathrm{H}$ to $-7 \mathrm{H}$. Although we did not observe Uvigerina in the upper five cores of Hole 647A, this form probably may have occurred with closer-spaced sampling, as it is present in the site-survey core. Site 647 contains the most complete Pleistocene stratigraphy, as well as assemblages that will allow detailed comparisons with other North Atlantic sites.

\section{Deep-Water History of the Eirik Ridge}

\section{Modern Hydrographic Setting}

At present, the deep-water masses in the northern Atlantic are derived from both northern and southern sources. Dilute Antarctic Bottom Water (AABW) is present below $2500 \mathrm{~m}$ in the Rockall Trough and Iceland basins and is presumed to flow along the eastern Atlantic margin in a weak cyclonic gyre (McCave and Tucholke, 1986). In the Rockall region, this water is joined by Norwegian Sea Deep Water (NSDW), which flows southward through the Faeroe-Shetland Channel and across the Wyville-Thompson Ridge and then turns northwestward to follow bathymetric contours around Rockall Bank. Additional amounts of NSDW flow across the Iceland-Scotland Ridge south of Iceland (Worthington and Volkmann, 1965). This flow travels along the eastern flank of the Reykjanes Ridge at a depth 
of $1300-2200 \mathrm{~m}$ and passes over the Garder Drift. The flow then descends and passes through the Charlie-Gibbs Fracture Zone into the Labrador Sea.

In today's Labrador Sea and Irminger Basin, the deep-water mass consists entirely of northern-source water. The IcelandScotland Overflow Water (ISOW) flows in a cyclonic loop along the western flank of the Reykjanes Ridge at a depth of around $3200 \mathrm{~m}$ (Worthington, 1976). Southwest of Iceland, ISOW is joined by cooler, denser Denmark Straits Overflow Water (DSOW), which descends beneath it. The DSOW is derived mainly from Arctic Intermediate Water, which forms by winter convection north of Iceland and overlies NSDW (Swift, 1986). This combined flow of ISOW and DSOW forms the Western Boundary Undercurrent, which flows southwestward along the eastern margin of Greenland and around the Eirik Ridge (McCave and Tucholke, 1986).

\section{History of Deep Circulation}

The dating of regional seismic reflectors at Site 646 reveals a much younger age for the Eirik Ridge than previously predicted. The Eirik Ridge was originally thought to be coeval with the Gloria Drift in the southern Labrador Sea, which is of Oligocene age (Tucholke and Mountain, 1986). Instead, the major period of drift sedimentation at Site 646 occurred in the Pliocene, although there is evidence of weaker currents occurring earlier. The seismic horizon marking the onset of drift deposition at this site is dated at approximately $4.5 \mathrm{Ma}$, based on the age-depth model for Hole 646B. Although there is no obvious hiatus in Hole 646B, a prominent seismic horizon observed within the drift sequence to the east of Site 646 was interpreted as indicating erosion. This horizon occurs between reflector Rl and the base of the drift, and by correlation with the reflectors in Hole 646B we interpreted the age of this erosional pulse as occurring between 4.5 and $2.5 \mathrm{Ma}$. This compares well with an age of 3-2 Ma for the "Blue" erosional event (see Arthur et al., this volume) in the western North Atlantic reported by Tucholke and Mountain (1986).

The history of the deep circulation over the Eirik Ridge can be reconstructed by comparing benthic foraminifer assemblages at Site 646 with those recovered during DSDP Legs 38 (Norwegian-Greenland Sea) and 94 (eastern Atlantic). Benthic assemblages in Hole 646B display turnovers that may be interpreted as reflecting changes in water-mass properties. The occurrence of N. umbonifera with smooth agglutinated taxa in Hole 646B and $N$. umbonifera assemblages in nannofossil Zones NN10 to NN11 and in Holes 608, 609, and 611C in the eastern Atlantic (Murray, 1987a; Thomas, 1987) point to the presence of a sluggish, corrosive deep water mass in the northern Atlantic basins in the Tortonian. This finding is supported by benthic carbon-isotope studies of Miller et al., (1987), which indicate that at $\sim 8 \mathrm{Ma}$, deep water in the North Atlantic did not differ isotopically from deep water in the Pacific. Murray (1987) interpreted the presence of $N$. umbonifera assemblages in DSDP Leg 94 holes as an indicator of "AABW-type" water in the North Atlantic in the late Miocene. The influence of corrosive deep water persisted into the early Pliocene at Site 611 on the Gardar Drift, where assemblages containing both $N$. umbonifera and modern NADW species were recovered. If ISOW were the predominant water mass over the Eirik Ridge in the early Pliocene, we might expect to find evidence of this entrained corrosive water reflected by assemblages in Hole 646B. However, the lack of any assemblages containing abundant $N$. umbonifera above seismic Unit 4 (Fig. 3 , Table 6) argues against the influence of this water mass. The assemblages of seismic Unit 3 are composed mainly of coarse agglutinated species and Melonis and are unlike any other North Atlantic Miocene assemblages. Instead, the assemblages from seismic Unit 3 more closely resemble pre-glacial assem- blages from intermediate and deep depths in the NorwegianGreenland Sea. A likely cause of this pattern is that DSOW has been the dominant deep water mass over the Eirik Ridge since the late Miocene, displacing the corrosive bottom water in the Irminger Basin at approximately 7.5 Ma (Fig. 7). This interpretation is supported by both carbon-isotopic evidence and the presence of displaced microfossils. Miller et al. (1987) noted that the benthic carbon-isotope record at Site 608 diverged from the Pacific record between 8 and $6 \mathrm{Ma}$. At $\sim 6 \mathrm{Ma}$, deep water in the North Atlantic was isotopically enriched with respect to Pacific water, indicating the production of "younger" deep waters analogous to modern NADW. Also, the reworked palynomorph Aquilapollenites was found above reflector R3 in Hole 646B, but not below (M. Head, pers. comm., 1987). Aquilapollenites is a high-latitude form known from the Cretaceous sediments of the northern North Sea, Greenland, and Svalbard (Batten, 1984). Sedimentologic evidence at Site 646 indicates increased bottom currents and increased sediment accumulation rates above the R3 seismic reflector (Srivastava, Arthur, et al., 1987).

The benthic foraminifer and seismic data indicate the period of maximum DSOW current velocities occurred between $\sim 4.5$ and 2.5 Ma. The disappearance of Rhizammina and the coarse grain size of sediments within the drift sequence is evidence of

\section{SITE 646 EIRIK RIDGE}

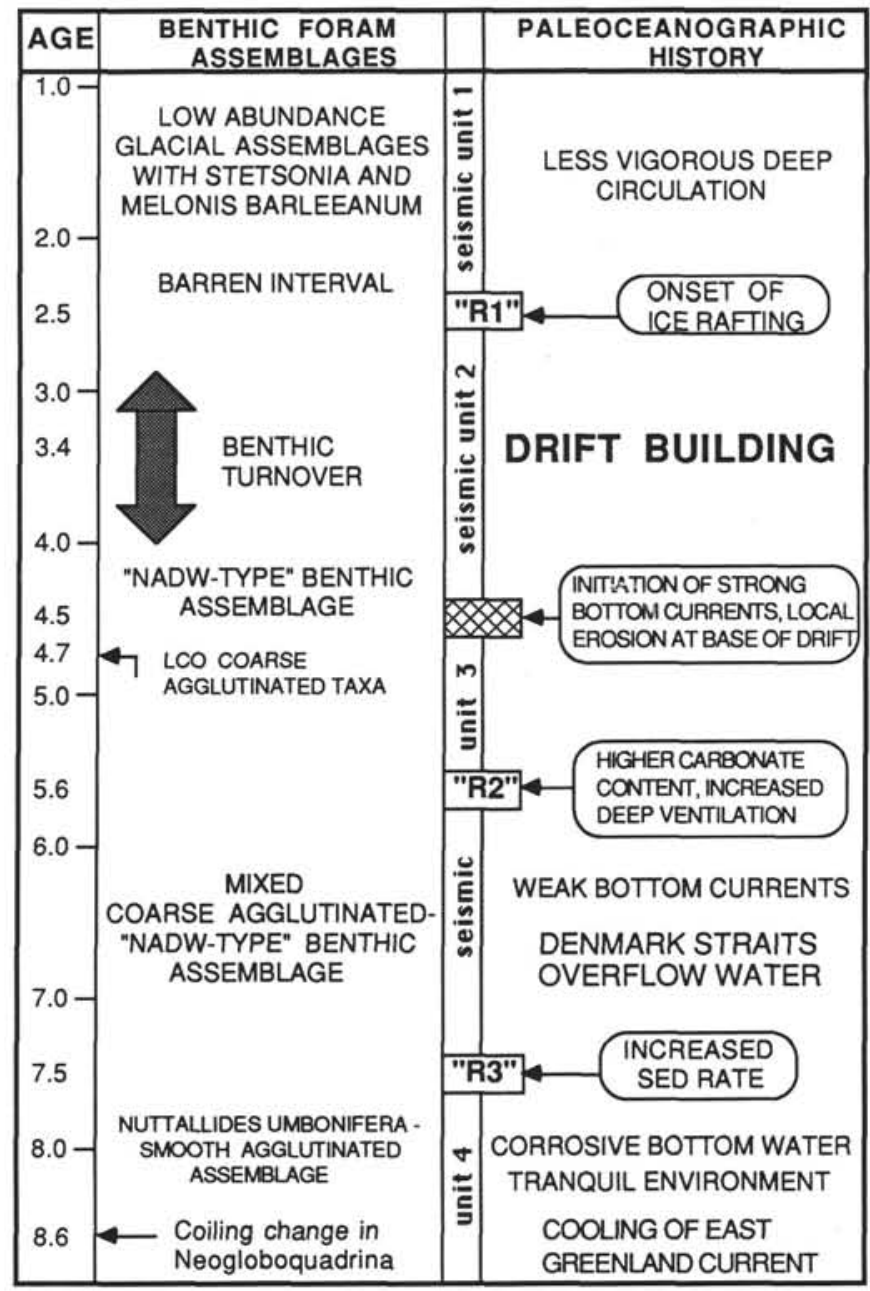

Figure 7. Summary of benthic foraminifer assemblages and the deep water history of the Eirik Ridge. 
deposition of drift sediments under conditions of increased current velocities. This contrasts with the model of Miller and Tucholke (1983), who interpreted the onset of drift sedimentation to reflect a decrease and stabilization of abyssal circulation. The approximately coeval occurrence of hiatuses in the western North Atlantic and Norwegian-Greenland Sea also suggests increased current velocities at this time. At Sites 338, 342, 348, 350 , and 647, glacial Pliocene-Pleistocene sediments rest on the Miocene, indicating a period of strong current activity possibly associated with the breakdown of a stable, stratified water column. The change from a coarse agglutinated assemblage in seismic Unit 3 of Hole $646 \mathrm{~B}$ to a calcareous assemblage in seismic Unit 2 probably reflects the increased ventilation of deep water associated with this current activity.

Our observation of DSOW (since $~ 7.5$ ) at Site 646 agrees with findings of Keigwin et al. (1987), who presented isotopic evidence for the continued production of NADW during the Messinian Salinity Crisis. Their results contradict earlier suggestions that the cutoff of Mediterranean Outflow Water during the Messinian should result in a cessation of NADW production in the Norwegian-Greenland Sea (Blanc and Duplessy, 1982). In the basal Pliocene to Messinian sediments beneath the sediment drift, Nuttallides umbonifera is present, but in lower proportions than before $7.5 \mathrm{Ma}$. The assemblage is still dominated by agglutinated taxa and species typical of modern NADW. The R2 reflector reflects a change from carbonate-poor sediments (below) to more carbonate-rich sediments (above). We interpreted this change as reflecting increased ventilation of the deep water at $\sim 5.6 \mathrm{Ma}$. At Site 609 in the eastern Atlantic, an analogous change from poor carbonate preservation (below) to increased carbonate preservation (above) began at $\sim 5.8 \mathrm{Ma}$ and reached a maximum at $\sim 5.3 \mathrm{Ma}$ (Hooper and Weaver, 1987), which suggests that this may be a basinwide event. Hooper and Weaver interpreted the latest Miocene peak in carbonate preservation as indicating increased contribution of northern-source deep water to the basin at this time.

Increased production of NADW may have been caused by a number of oceanographic and climatic factors. Cooler late Miocene sea-surface temperatures at high latitudes, which culminated in the proposed 5.2 to $4.8 \mathrm{Ma}$ glacial events reported by Keigwin et al. (1987) and Keigwin (in press), may have contributed to greater NADW production. Indeed, the appearance of DSOW at Site 646 is preceded by a coiling change in Neogloboquadrina atlantica (at $\sim 8.6 \mathrm{Ma}$ ), which indicates cooling of the surface waters in the East Greenland Current (Aksu and Kaminski, this volume). With the reopening of the Mediterranean at 4.83 Ma (Zijderveld et al., 1986), the northward advection of saline water to the Norwegian-Greenland Sea, combined with cool sea-surface temperatures, may have resulted in the production of denser, more oxygenated intermediate and deep waters. This raises the possibility that Mediterranean water may have been a contributing factor to the presence of hiatuses, the onset of drift sedimentation at Site 646, and the LCO of agglutinated taxa. The period of drift formation also correlates with the maximum northward penetration of AABW observed in the eastern Atlantic in the early Pliocene by Murray (1987). This correlation suggests that a feedback mechanism or "teleconnection" between NADW and AABW may have operated in the early Pliocene analogous to today (see Johnson, 1982).

\section{CONCLUSIONS}

Throughout much of the stratigraphic record recovered at Site 645 , benthic foraminifer assemblages are endemic and cannot be correlated with any site in the Atlantic. The Miocene foraminifer assemblage consists mainly of agglutinated foraminifers that have poorly constrained stratigraphic ranges. Scattered calcareous benthic species can be seen in the mid-Miocene, but these are boreal in nature. Above the barren interval in Site 645, a Pliocene to Pleistocene calcareous benthic assemblage dominated by Epistominella takayanagii was recovered. This type of assemblage has no modern analog. The Pleistocene Stetsonia assemblage in the upper $90 \mathrm{~m}$ of Site 645 indicates a deep environment similar to today's Baffin Bay.

Drilling at Site 646 recovered benthic foraminifer assemblages that provide information for interpreting the depositional environment and water mass history of the Eirik Ridge (Fig. 7). Before $\sim 7.5 \mathrm{Ma}$, an assemblage dominated by Nuttallides umbonifera and smooth agglutinated species points to a tranquil environment with corrosive deep water. After $\sim 7.5$ $\mathrm{Ma}$, Denmark Straits Overflow Water was present over the Eirik Ridge. Above the R3 seismic reflector, the benthic assemblage consists mainly of coarse agglutinated taxa with affinities to the Norwegian-Greenland Sea. The onset of drift sedimentation at $\sim 4.5 \mathrm{Ma}$ was accompanied by a change to a predominantly calcareous assemblage. Another faunal turnover took place between 3 and $4 \mathrm{Ma}$, as low-latitude species disappeared. This turnover appears to be diachronous from west to east, beginning in the early Pliocene at Site 646 and in the late Pliocene at DSDP sites in the eastern Atlantic. Drift formation ceased at $\sim 2.5 \mathrm{Ma}$, concomitant with the first occurrence of ice-rafted sediments. Benthic foraminifer species that have arctic affinities first appeared in the early Pleistocene.

Pliocene and Pleistocene benthic foraminifer assemblages at Site 647 differ from those recovered at the other Leg 105 sites in containing $N$. umbonifera. These assemblages provide the closest analog to other North Atlantic sites, with glacial and interglacial benthic assemblages most similar to those reported in other parts of the North Atlantic (e.g., Schnitker, 1974). Site 647 also contains an adequate planktonic microfossil and magnetic reversal record, which allowed more accurate age determinations than at the other two sites.

\section{ACKNOWLEDGMENTS}

This study was supported by grants from the Texas A\&M Research Foundation/U.S. Scientific Program (1892-B05). M. Kaminski also was supported by grants from the Geological Society of America (86-3599) and the Margaret M. Patterson Memorial Scholarship Fund. This is a contribution of the Deep Water Benthic Foraminifer Project, which is conducted by W. A. Berggren and colleagues at the Woods Hole Oceanographic Institution and is sponsored by a consortium of oil companies (Atlantic Richfield Co., British Petroleum, Chevron-Gulf, Elf-Aquitane, Exxon, Mobil, Phillips, Shell International, Shell USA, Standard Oil of Ohio, Texaco, and Union Oil of California).

We thank the Ocean Drilling Program for the opportunity to participate during Leg 105 and for providing samples. Various aspects of this study benefited from discussions of the senior author with M. A. Arthur, W. A. Berggren, M. J. Head, G. D. Jones, K. G. Miller, H. L. Sanders, B. E. Tucholke, and J. C. Zachos. We thank Amy Pallant and Frank Thomas for providing technical assistance. M. A. Arthur, W. A. Berggren, S. Srivastava, G. D. Jones, K. G. Miller, and an anonymous reviewer read the manuscript and provided many useful comments. This is contribution 6525 of the Woods Hole Oceanographic Institution.

\section{REFERENCES}

Aksu, A. E., 1983. Holocene and Pleistocene dissolution cycles in deepsea cores of Baffin Bay and Davis Strait: paleoceanographic implications. Mar. Geol., 53:331-340.

Batten, D. J., 1984. Palynology, climate and the development of Late Cretaceous floral provinces in the Northern Hemisphere: a review. In Brenchley, P. J. (Ed.), Fossils and Climate: New York (John Wiley \& Sons), 127-164.

Berggren, W. A., and Schnitker, D., 1983. Cenozoic marine environments in the North Atlantic and Norwegian-Greenland Sea. In Bott, M. H., Saxov, S., Talwani, M., and Thiede, J. (Eds.), Structure and Development of the Greenland-Scotland Ridge. NATO Conf. Ser., IV:495-548.

Berggren, W. A., Kent, D. V., and Van Couvering, J. A., 1985. Neogene geochronology and chronostratigraphy. In Snelling N. J. (Ed.), The 
Geochronology of the Geological Record. Geol. Soc. (London), Mem. 10:210-260.

Blanc, P. L., and Duplessy, J. C., 1982. The deep water circulation during the Neogene and the impact of the Messinian salinity crisis. Deep Sea Res., 29:1391-1414.

Bremer, M. L., and Lohmann, G. P., 1982. Evidence for primary control of the distribution of certain Atlantic Ocean benthonic foraminifera by degree of carbonate saturation. Deep Sea Res., 29:987998.

Gradstein, F. M., and Berggren, W. A., 1981. Flysch-type agglutinated foraminiferal stratigraphy and the Maestrichtian to Paleogene history of the Labrador and North Seas. Mar. Micropaleontol., 6:211268.

Gradstein, F. M., and Agterberg, F. P., 1982. Models of Cenozoic foraminiferal stratigraphy-Northwestern Atlantic Margin. In Cubitt, J. M., and Raymant, R. A. (Eds.), Quantitative Stratigraphic Correlation: New York (John Wiley \& Sons), 119-170.

Henderson, G., Schiener, E. J., Risum, J. B., Croxton, C. A., and Anderson, B. B., 1981. The West Greenland Basin. In Kerr, J. W., Fergusson, A. J., and Machan, L. C. (Eds.), Geology of the North Atlantic Borderlands. Can. Soc. Pet. Geol. Mem., 7:399-428.

Hooper, P.W.P., and Weaver, P.P.E., 1987. Paleoceanographic significance of late Miocene to early Pliocene planktonic foraminifers at Deep Sea Drilling Project Site 609. In Ruddiman, W. F., Kidd, R. B., Thomas, E., et al., Init. Repts. DSDP, 94: Washington (U.S. Govt. Printing Office), 925-934.

Johnson, . . A., 1982. Abyssal teleconnections: interactive dynamics of the deep ocean circulation. Palaeogeogr., Palaeoclimatol., Palaeoecol., 38:93-128.

Jones, R. W., and Charnock, M. A., 1985. "Morphogroups" of agglutinating foraminifera. Their life positions and feeding habits and potential applicability in (paleo)ecological studies. Rev. Paleobiol., 4: 311-320.

Jumars, P. A., and Gallagher, E. D., 1982. Deep-sea community structure: three plays on the benthic proscenium II. Biological environmment of the deep Sea. In Ernst, W. G., and Morin, J. G. (Eds.), The Environment of the Deep Sea: Englewood Cliffs, NJ (PrenticeHall), 217-255.

Kaminski, M. A., 1985. Evidence for control of abyssal agglutinated foraminiferal community structure by substrate disturbance: results from the HEBBLE Area. Mar. Geol., 66:113-131.

Keigwin, L. D., (in press). Toward a high resolution chronology for latest Miocene paleoceanographic events. Paleoceanography.

Keigwin, L. D., Aubry, M. P., and Kent, D. V., 1987. North Atlantic late Miocene stable isotope stratigraphy, biostratigraphy, and magnetostratigraphy. In Ruddiman, W. F., Kidd, R. B., Thomas, E., et al., Init. Repts. DSDP, 94: Washington (U.S. Govt. Printing Office), 935-964.

Kennett, J. P., and Srinivasan, M. S., 1983. Neogene Planktonic Foraminifera: Stroudsburg, PA (Hutchinson Ross).

King, C., 1983. Cainozoic micropaleontological biostratigraphy of the North Sea. Inst. Geol. Sci. Rept., 82/7:1-40.

Klose, G. W., Malterre, E., McMillan, N. J., and Zinkan, C. G., 1982. Petroleum exploration offshore southern Baffin Island, Northern Labrador Sea, Canada. In Embry, A. F., Balkwill, H. R. (Eds.), Arctic Geology and Geophysics. Can. Soc. Pet. Geol. Mem., 8:233244.

Lagoe, M. B., 1977. Recent benthic foraminifera from the central Arctic Ocean. J. Foram. Res., 7:106-129.

Laughton, A. S., Berggren, W. A., et al., 1972. Init. Repts. DSDP, 12: Washington (U.S. Govt. Printing Office).

Levinton, J. S. 1982. Marine Ecology: Englewood Cliffs, NJ (PrenticeHall).

Lonsdale, P., 1977. Clustering of suspension-feeding macrobenthos near abyssal hydrothermal vents at oceanic spreading centers. Deep Sea Res., 24:857-863.

McCave, I. N., and Tucholke, B. E., 1986. Deep current-controlled sedimentation in the western North Atlantic. In Vogt, P. R., and Tucholke, B. E., (Eds.), The Geology of North America., The Western North Atlantic Region (Vol. M): Boulder, CO. (Geological Society of America), 451-468.

Miller, K. G., Gradstein, F. M., and Berggren, W. A., 1982. Late Cretaceous to early Tertiary agglutinated benthic foraminifera in the Labrador Sea. Micropaleontology, 28:1-30.
Miller, K. G., and Tucholke, B. E., 1983. Development of Cenozoic abyssal circulation south of the Greenland-Scotland Ridge. In Bott, M. H., Saxov, S., Talwani, M., and Thiede, J. (Eds.), Structure and Development of the Greenland-Scotland Ridge. NATO Conf. Ser., IV:549-590.

Miller, K. G., Fairbanks, R. G., and Thomas, E., 1987. Benthic foraminiferal carbon isotope records and the development of abyssal circulation in the eastern North Atlantic. In Ruddiman, W. F., Kidd, R. B., Thomas, E., et al., Init. Repts. DSDP, 94: Washington (U.S. Govt. Printing Office), 981-996.

Murray, J. W., 1984. Paleogene and Neogene benthic foraminifers from the Rockall Plateau. In Roberts, D. G., and Schnitker, D., et al., Init. Repts. DSDP, 81: Washington (U.S. Govt. Printing Office), 503-529.

Murray, J. W., 1987. Benthic foraminifers and Neogene water masses at Deep Sea Drilling Project Leg 94 North Atlantic Sites. In Ruddiman, W. F., Kidd, R. B., Thomas, E., et al., Init. Repts. DSDP, 94: Washington (U.S. Govt. Printing Office), 965-980.

Murray, J. W., 1987. Bolboforma from North Atlantic sites, Deep Sea Drilling Project Leg 94. In Ruddiman, W. F., Kidd, R. B., Thomas, E., et al., Init. Repts. DSDP, 94: Washington (U.S. Govt. Printing Office), 813-814.

Schroder, C. J., 1986. Deep-water arenaceous foraminifera in the Northwest Atlantic Ocean. Can. Tech. Rept. Hydrogr. Ocean Sci., 71:1191.

Scott, D. B., 1987. Quaternary benthic foraminifers from Deep Sea Drilling Project Sites 612 and 613, Leg 95, New Jersey Transect. In Poag, C. W., Watts, A. B., et al., Init. Repts. DSDP, 95: Washington (U.S. Govt. Printing Office), 313-337.

Scott, D. B., MacKinnon, K. D., and Baki, V., 1987. Arctic Ocean benthonic foraminifera, stable isotope stratigraphy and Quaternary paleoenvironment. 12th Int. INQUA Cong., Ottawa, July 1987. (Abstracts and Program), 261.

Schnitker, D., 1974. West Atlantic abyssal circulation during the past 120,000 years. Nature, 248:385-387.

Shipboard Scientific Party, 1987a. Site 646. In Srivastava, S. P., Arthur, M., et al., Proc. ODP, Init. Repts., 105: College Station, TX (Ocean Drilling Program), 419-674.

Shipboard Scientific Party, 1987b. Site 647. In Srivastava, S. P., Arthur, M., et al., Proc. ODP, Init. Repts., 105: College Station, TX (Ocean Drilling Program), 675-905.

Shipboard Scientific Party, 1987c. Site 645. In Srivastava, S. P., Arthur, M., et al., Proc. ODP, Init. Repts., 105: College Station, TX (Ocean Drilling Program), 61-418.

Srivastava, S. P., and Tapscott, C. R., 1986. Plate kinematics of the North Atlantic. In Vogt, P. R., and Tucholke, B. E., (Eds.), The Geology of North America, The Western North Atlantic Region (Vol. M): Boulder, CO. (Geological Society of America), 379-404.

Swift, J. H., 1986. The Arctic waters. In Hurdle, B. G., (Ed.), The Nordic Seas: New York, Berlin, Hiedelberg (Springer-Verlag), 129-153.

Talwani, M., Udintsev, G., et al., 1976. Init. Repts. DSDP, 38: Washington (U.S. Govt. Printing Office).

Thomas, F. C., 1985. Lower Scotian Slope benthic foraminiferal faunas past and present, with taxonomic outline [M.Sc. thesis]. Dalhousie University, Halifax.

Thomas, E., 1987. Late Oligocene to Recent benthic foraminifers from Deep Sea Drilling Project Sites 608 and 610, Northeastern Atlantic. In Ruddiman, W. F., Kidd, R. B., Thomas, E., et al., Init. Repts. DSDP, 94: Washington (U.S. Govt. Printing Office), 813-814.

Tucholke, B. E., and Mountain, G. S., 1986. Tertiary paleoceanography of the western North Atlantic Ocean. In Vogt, P. R., and Tucholke, B. E., (Eds.), The Geology of North America, The Western North Atlantic Region (Vol. M): Boulder, CO (Geological Society of America), 631-650.

Van Morkhoven, F., Berggren, W. A., and Edwards, A. S., 1986. Cenozoic cosmopolitan deep-water benthic foraminifera. Bull. Centres Rech. Explor. Prod. Elf-Aquitaine (Pau), Mem. 11.

Verdenius, J. G., and Van Hinte, J. E., 1983. Central Norwegian-Greenland Sea: Tertiary arenaceous foraminifera, biostratigraphy and environment. Proc. First Workshop on Arenaceous Foram., 7-9 Sept., 1981. Continental Shelf Inst. Publ., 108:173-224.

Weaver, P.P.E and Clement, B. M., 1986. Synchroneity of Pliocene planktonic foraminiferal datums in the North Atlantic. Mar. Micropaleontol., 10:295-307. 
Worthington, L. V., 1976. On the North Atlantic Circulation: Baltimore (Johns Hopkins University Press), Johns Hopkins Ser. in Oceanogr., 6.

Worthington, L. V., and Volkmann, G. H., 1965. The volume transport of the Norwegian Sea Overflow Water in the North Atlantic. Deep Sea Res., 12:667-676.

Young, F. G., and McNeil, D. H., 1983. Cenozoic stratigraphy of the MacKenzie Delta, Northwest Territories. Geol. Surv. Can. Bull., $336: 1-63$.
Zijderveld, J.D.A., Zachariasse, J. W., Verhallen, P. J., and Hilgen, F. J., 1986. The age of the Miocene-Pliocene boundary. News. Stratigr., 16:169-181.

Date of initial receipt: 23 June 1988

Date of acceptance: 9 November 1988

Ms B105-123

Abbreviations of species names: Ebrd $=$ Eggerella bradyi $($ Cushman $)$, SIPH $=$ Siphotextularia spp., MART $=$ Martinotiella spp., Kbrd $=$ Karreriella bradyi $($ Cushman $)$, $\mathrm{Ssch}=$ Sigmiolopsis schlumbergeri (Silvestri), LAGM = Lagenammina sp., RHIZ = Rhizammina spp., PSAM = Psammosphaera fusca $\mathrm{Schultze,} \mathrm{AMMB}=$ Ammobaculites spp., ASCH $=$ Aschemonella spp., TROC $=$ Trochammina spp., RECV $=$ Recurvoides spp., Cpus $=$ Cyclammina pusilla $(\mathrm{Brady}), \mathrm{HAPL}=$ Haplophragmoides sp., REOP = Reophax pilulifer Brady, Khor = Karreriella horrida $\mathrm{Mjatliuk,} \mathrm{AMMS} \mathrm{=} \mathrm{Ammosphaeroidina} \mathrm{sp} .$, TROI $=$ Trochamminoides sp., $\mathrm{ADER}=$ Adercotrema, glomerata, $($ Brady), $\mathrm{AMMD}=$ Ammodiscus spp., GLOM = Glomospira gordialis (Jones and Parker), Ccan = Cyclammina cancellata Brady, PYRG = Pyrgo murrhina (Schwager), Qsem = Quinquiloculina seminula (Linne), Qang = Quinqueloculina sp. $($ angular), Qrnd = Quinqueloculina sp. (rounded), Tarc $=$ Triloculina arctica $($ Cushman), Ttri $=$ Triloculina trihedra Loeblich and Tappan, OPTH $=$ Opthalmidium sp., ORID $=$ Oridorsalis umbonatus (Reuss), Mpom = Melonis pompilioides (Fichtel and Moll), Psub = Pullenia subcarinata (d'Orbigny), CIB = Cibicidoides sp. (transitional between C. bradyi and $P$. wuellerstorfi $), \mathrm{STIL}=$ Stilostomella spp., DENT $=$ Dentalina spp., FISS $=$ Fissurina spp., OOLN $=$ Oolina spp., LAGN $=$ Lagena spp., Gaur $=$ Globobulimina auriculata (Bailey), Gpac = Globobulimina pacifica Cushman, Pwue $=$ Planulina wuellerstorfi $($ Schwager), ELPH $=$ Elphidium spp., ?ENT $=$ entosolenian, possibly Glandulina sp., Mbar = Melonis barleeanum (Williamson), GOID = Gyroidinoides spp., NODO = Nodosaria spp., Nstr $=$ Nodosaria sp. $($ striate), SARA = Saracenaria spp., UVIG = Uvigerina peregrina Cushman, Usma $=$ Uvigerina $\mathrm{sp}$. $(\mathrm{small})$, Numb $=$ Nuttallides umbonifera $($ Cushman $)$, PSPL $=$ Pseudopolymorphina sp., Pbul = Pullenia bulloides (d'Orbigny), LENT = Lenticulina spp., POLY = polymorphinids, Hele = Hoeglundina elegans $(\mathrm{d}$ 'Orbigny), LATI = Laticarinina pauperata (Parker and Hones), Eexi $=$ Epistominella exigua $($ Brady), Gsub $=$ Globocassidulina subglobosa $($ Brady), EPON $=$ Eponides spp., TOSA $=$ Tosaia hanzawai Takayanagi, FURS = Fursenkoina fusiformis $($ Williamson), Iter $=$ Islandiella teretis $($ Tappan $)$, Bfri $=$ Buccella frigida $($ Cushman), GYRO = Gyroidina orbicularis d'Orbigny, Clob = Cibicidoides lobatulus (Walter and Jacob), PLEU = Pleurostomella spp., SPHA $=$ Sphaeroidina bulloides d'Orbigny, FRON = Frondicularia spp., BRIZ $=$ Brizalina spp., Npyr $=$ Nodosaria pyrula d'Orbigny, Cbrd $=$ Cibicidoides bradyi $($ Trauth $)$, CIBs $=$ Cibicidoides spp. ind., Bala $=$ Bulimina alazanensis Cushman, Prnz = Planulina renzi Cushman and Stainforth, NONI $=$ Nonion spp., $\mathrm{H}^{1}=\mathrm{Shannon-Wiener} \mathrm{Diversity.}$ 
APPENDIX

Benthic Foraminifers in Hole 646B

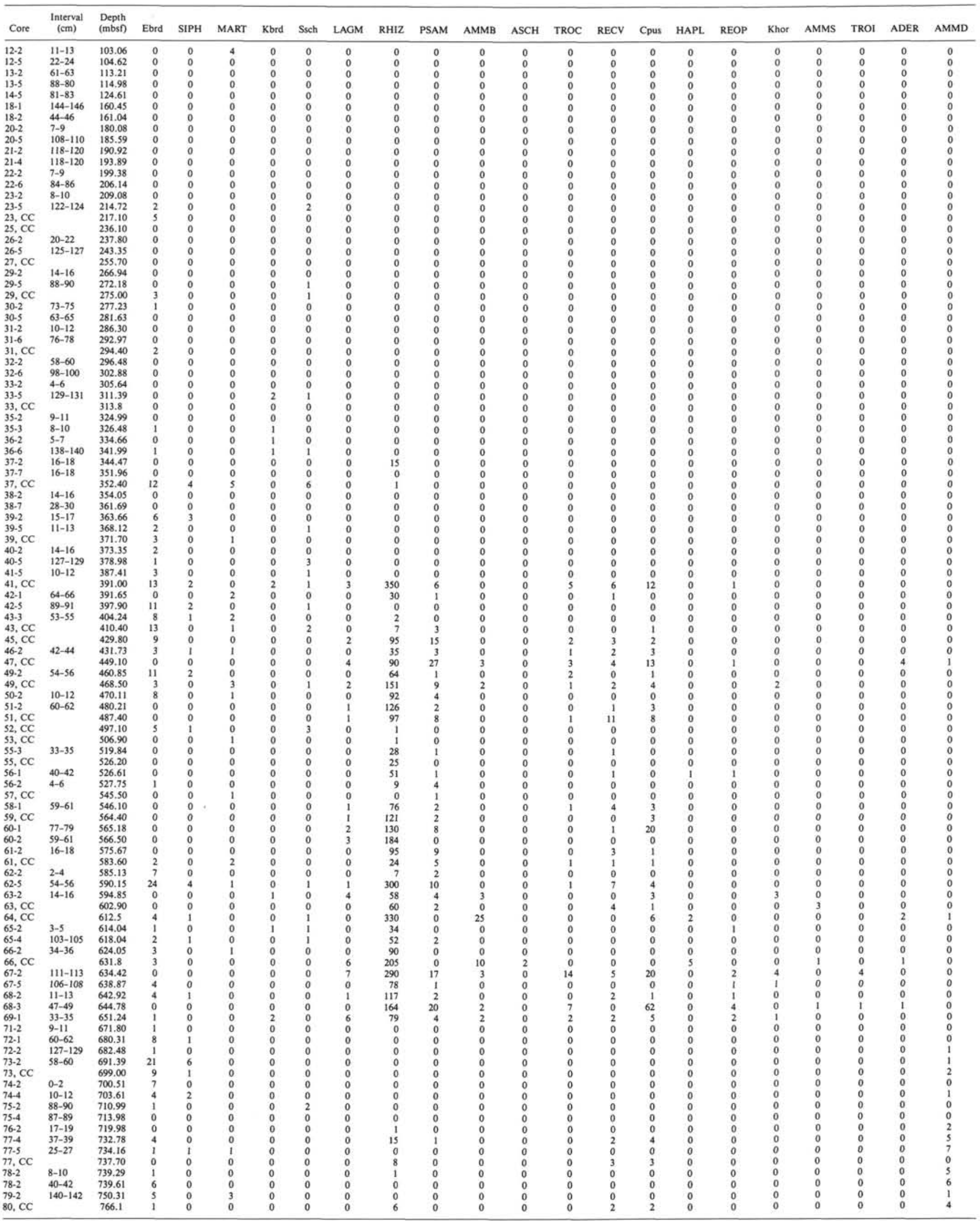


Appendix (continued).

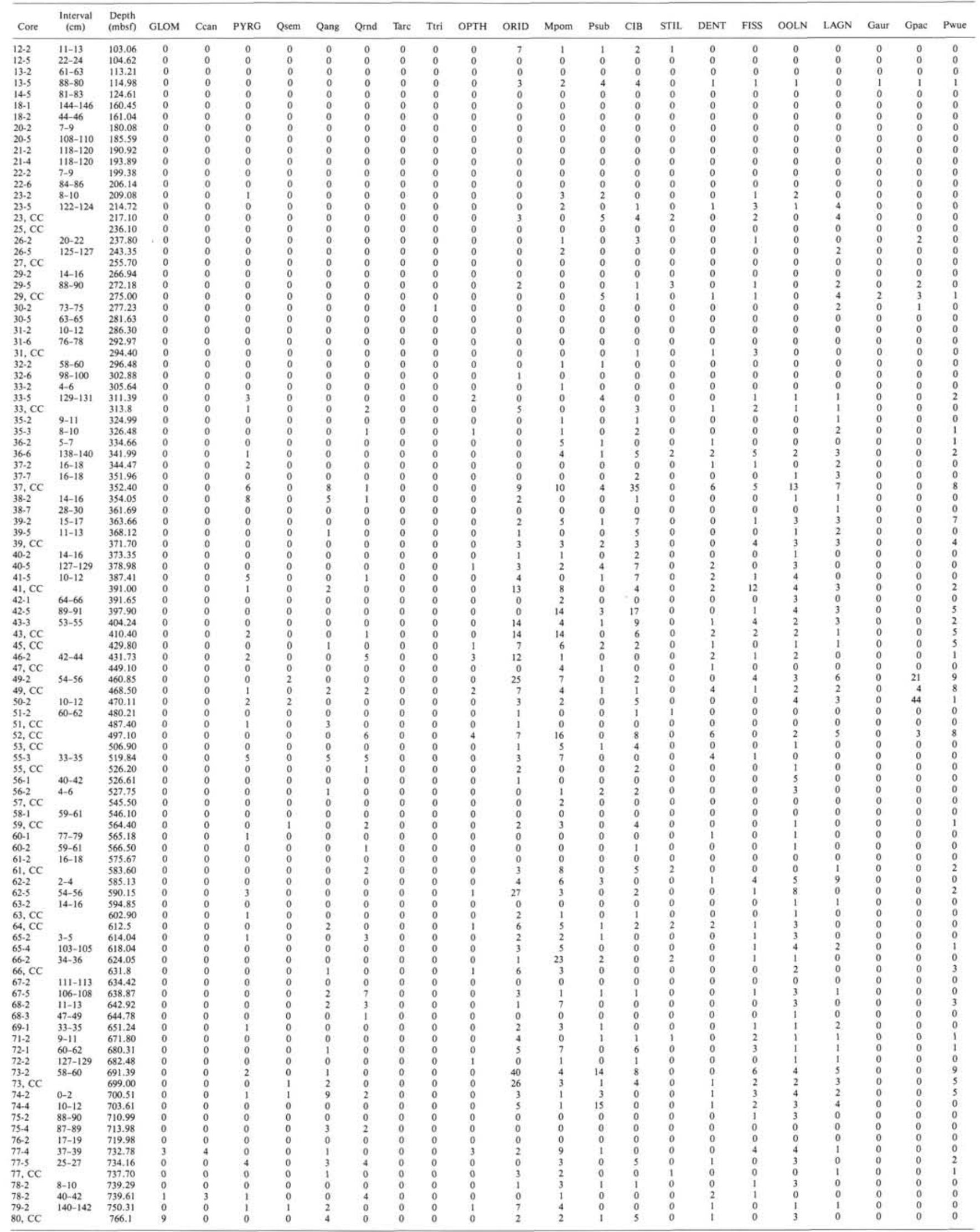


Appendix (continued).

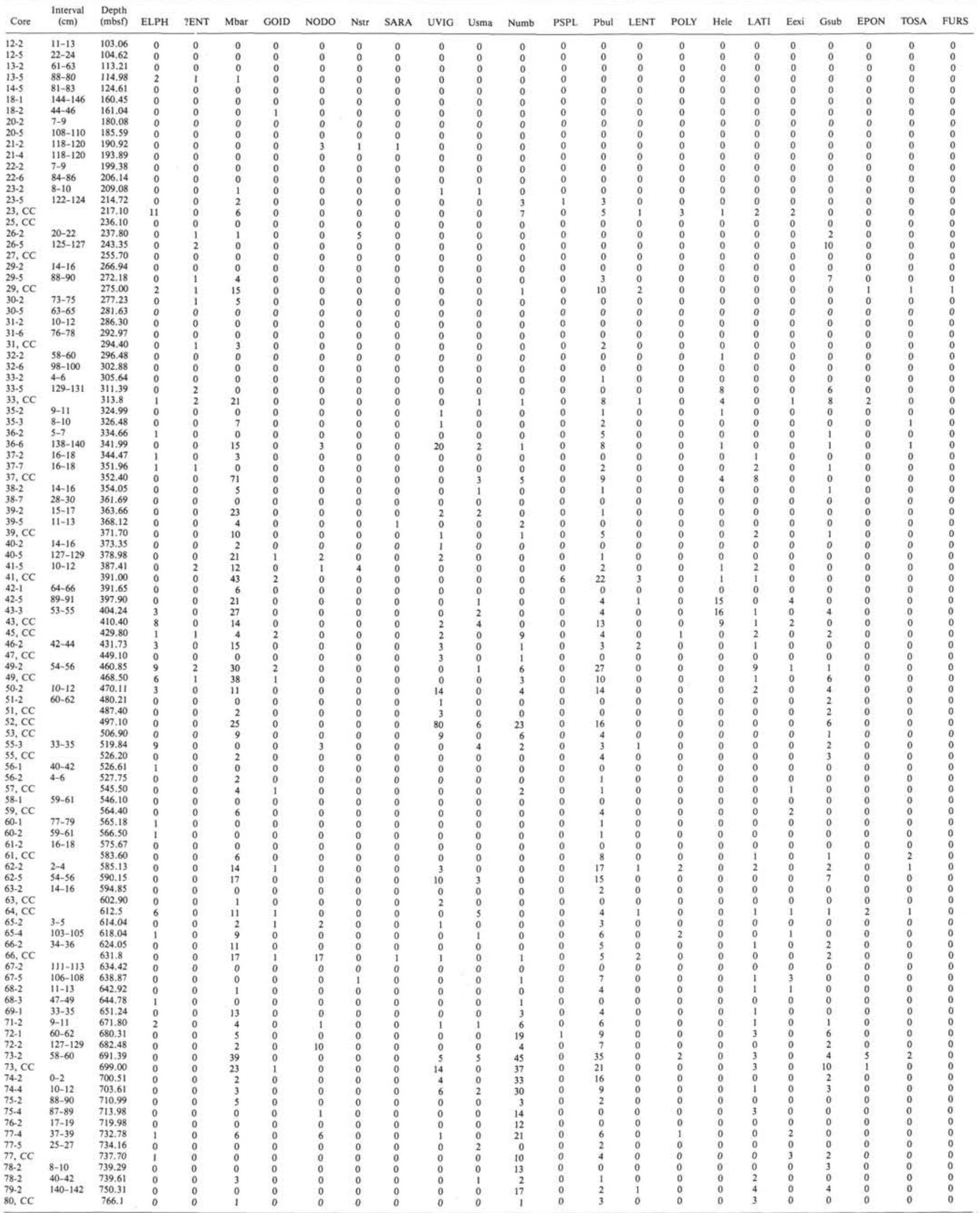


Appendix (continued).

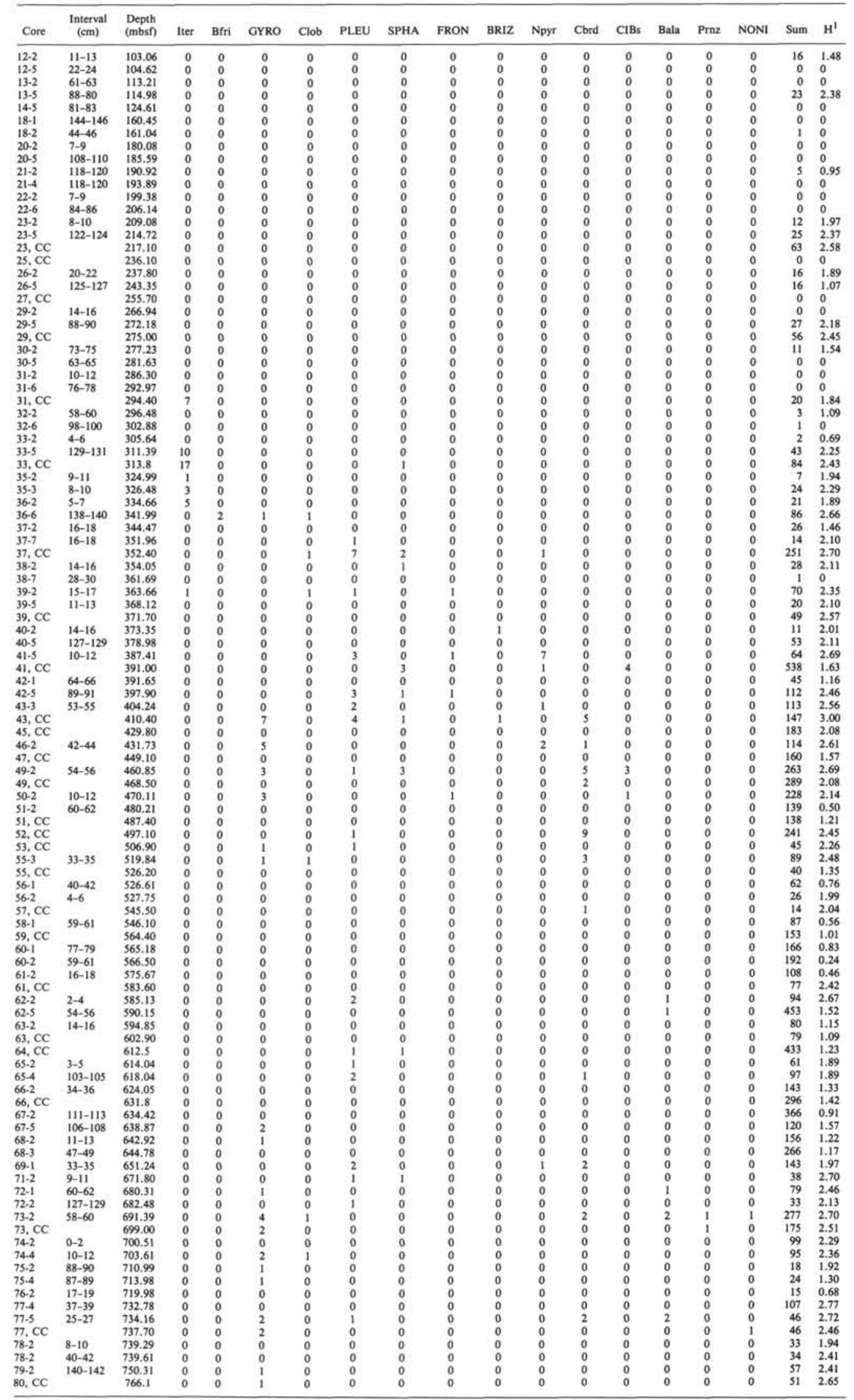




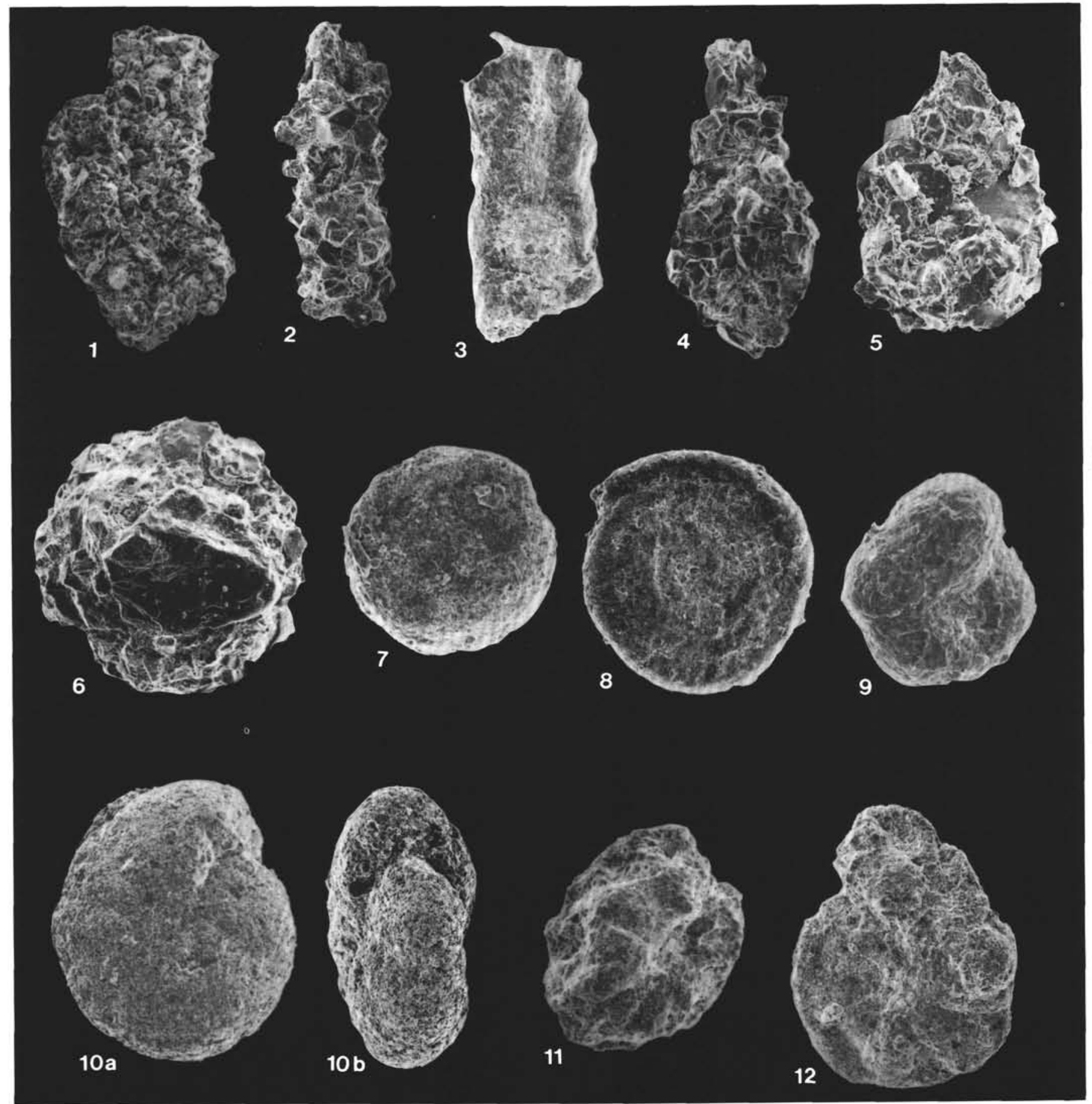

Plate 1. Agglutinated taxa from Hole 645E. 1 and 2. Rhizammina sp., Sample 105-645E-43X-1, 3-6 cm, 33X. 3. Bathysiphon sp., Sample 105645E-53X-5, 98-100 cm, 33X. 4 and 5. Lagenammina sp., Sample 05-645E-43X-1, 3-6 cm, 55X. 6. Psammosphaera fusca Schultze, Sample 105645E-54X-1, 90-92 cm, 66X. 7. Psammosphaera sp., Sample 105-645E-50X-2, 84-86 cm, 11OX. 8. Ammodiscus sp., Sample 105-645E-76X-6, $38-40 \mathrm{~cm}, 125 \mathrm{X}$. 9. Trochammina sp 5, Sample 105-645E-77X-1, 107-109 cm, 150X. 10a,b. Cyclammina cancellata Brady, Sample 105-645E43X-1, 3-6 cm, 33X. 11 and 12. Haplophragmoides sp., Sample 105-645A-76R-6, 38-40 cm, 110X. 


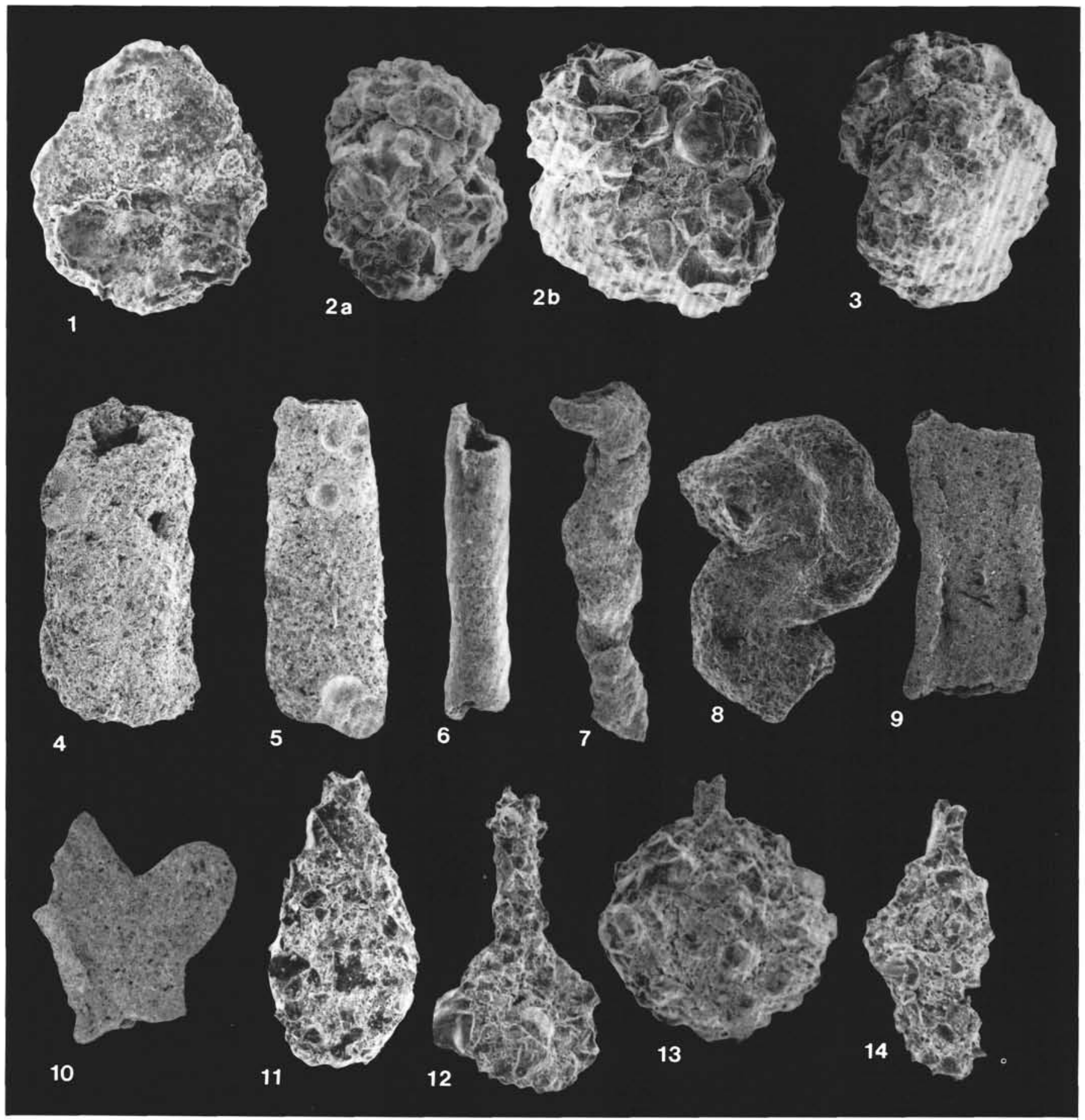

Plate 2. Agglutinated taxa from Sites 645 and 646. 1. Trochammina sp. (flat), Sample 105-645E-77R-1, 107-109 cm, 150X. 2. Haplophragmoides sp. (coarse), Sample 105-645E-56R-4, 137-140 cm, 66X. 3. Recurvoides sp. Sample 105-645E-46R-3, 95-97 cm, 83X. 4 and 5. Rhizammina sp., Sample 105-646B-62X-5, 54-56 cm. 6. Bathysiphon sp., Sample 105-646B-78X-2, 8-10 cm. 7. Rhizammina indivisa Brady, Sample 105646B-68X-3, 47-49 cm, 66X. 8. Rhizammina indivisa Brady, Sample 105-646B-68X-3, 47-49 cm, 55X. 9 and 10. Dendrophrya sp., Sample 105646B-58X-1, 59-61 cm, 28X. 11. Lagenammina sp., Section 105-645E-47X, CC, 83X. 12 and 13. Saccammina sp., Section 105-645E-47X, CC, 83X. 14. Reophax subfusiformis Earland emend. Hoglund, Section 105-645E-47X, CC, 96X. 


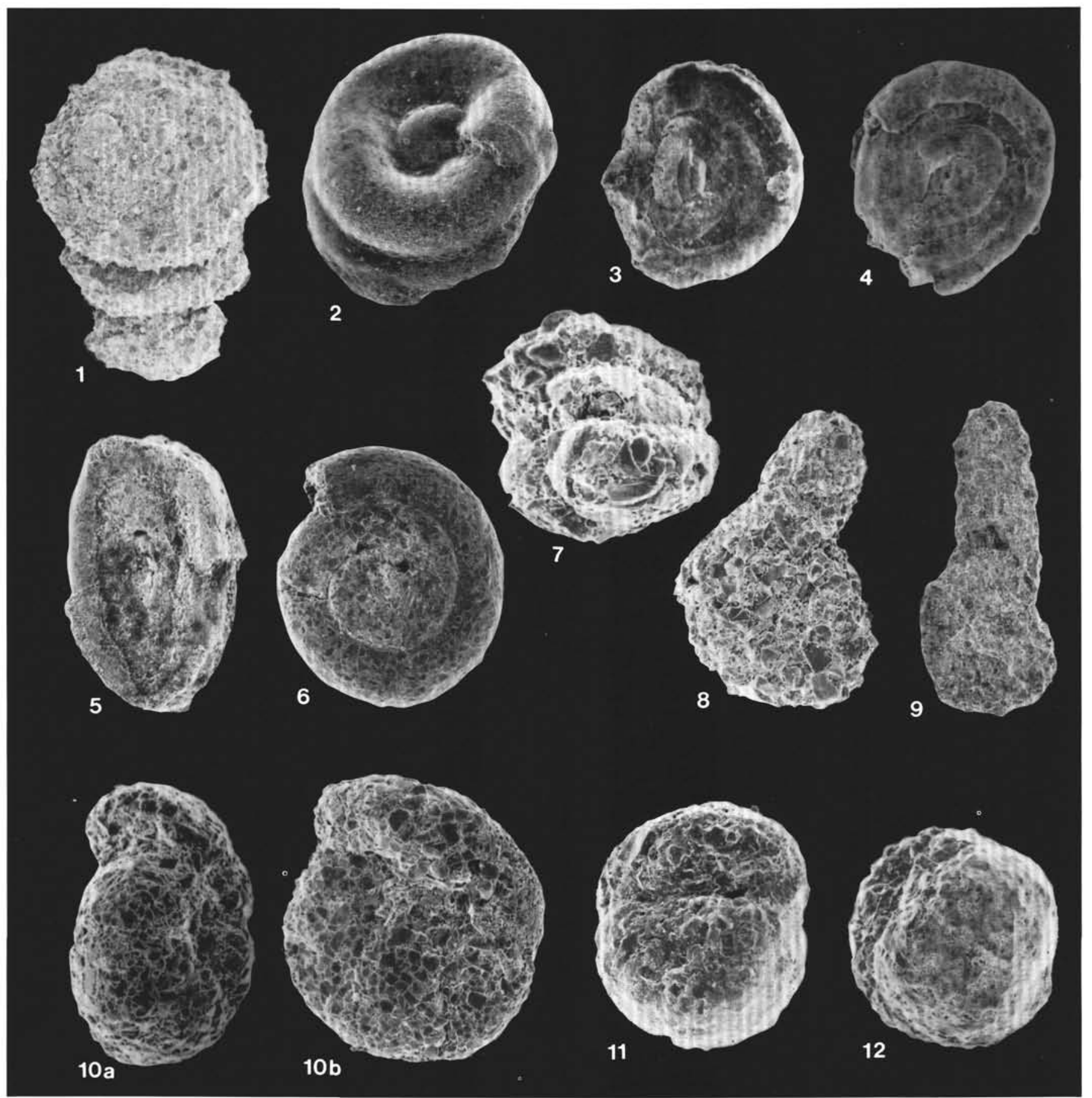

Plate 3. Agglutinated taxa from Hole 646B. 1. Reophax pilulifer Brady, Section 105-646B-47X, CC, 38X. 2. Glomospira gordialis (Jones and Parker), Sample 105-646B-78X-2, 40-42 cm 83X. 3 and 4. Glomospirella sp., Sample 105-646B-77X-5, 25-27 cm, $150 \mathrm{X}$. 5. Ammodiscus sp., Sample 105-646B-78X-2, 40-42 cm, 110X. 6. Ammodiscus incertus (d'Orbigny), Sample 105-646B-77X-4, 37-39 cm, 60X. 7. Adercotrema glomerata (Brady), Section 105-646B-66X, CC, 137X. 8. Ammobaculites sp., Sample 105-646B-69X-1, 33-35 cm, 60X. 9. Ammomarginulina sp., Section 105-646B-47X, CC, 50X. 10a,b. Recurvoides turbinatus (Brady), Section 105-646B-66X, CC, 55X. 11 and 12. Recurvoides contortus Earland, Section 105-646B-51X,CC, 110X. 

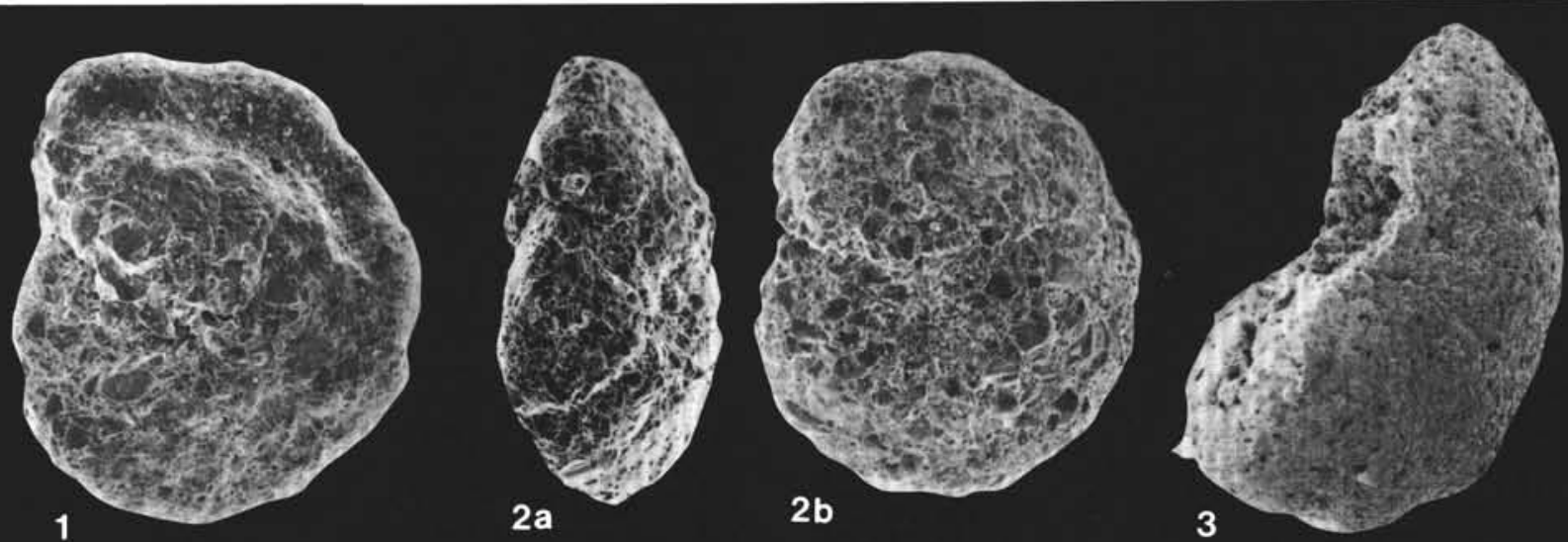
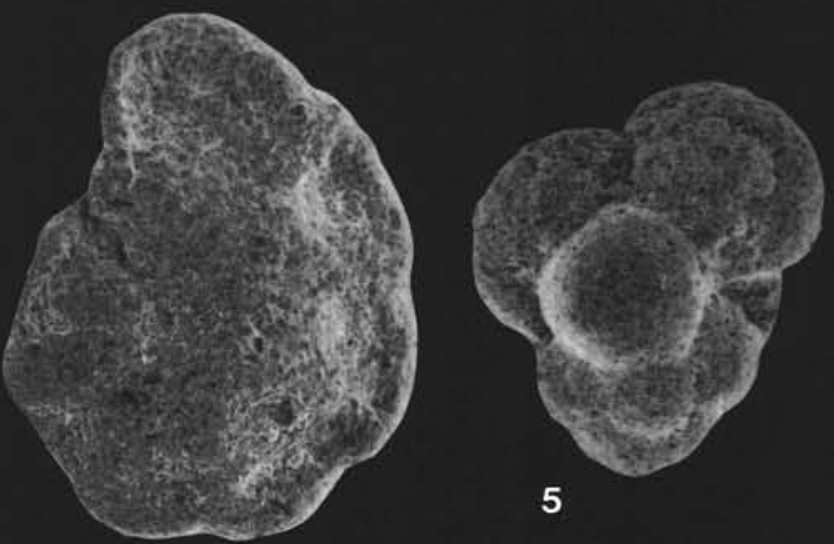

5

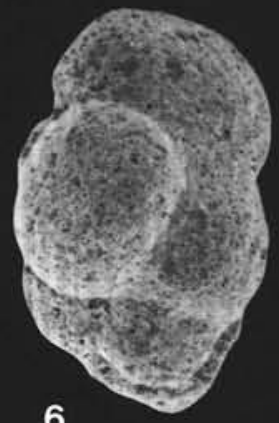

6

4

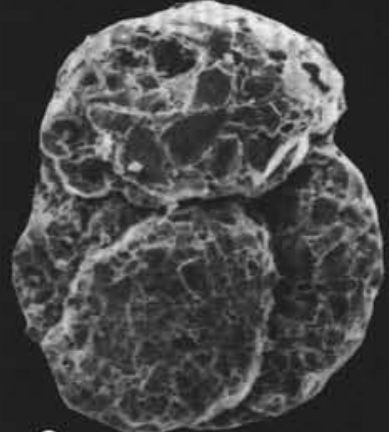

8

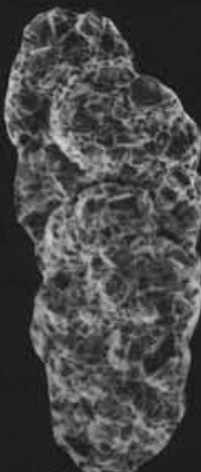

9

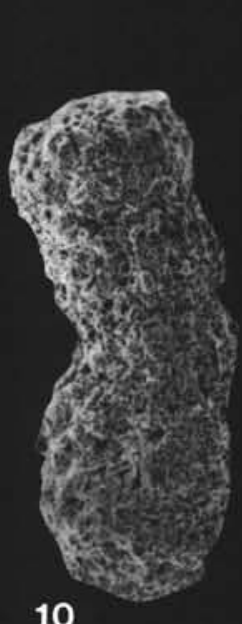

10

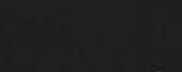

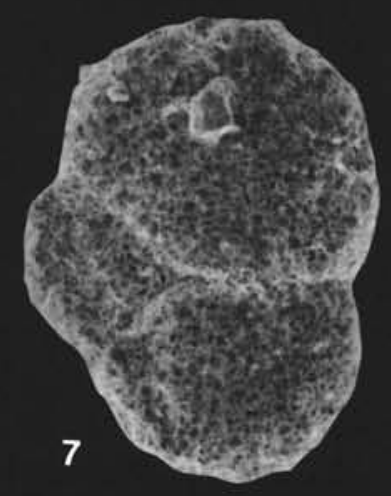

Plate 4. Agglutinated taxa from Hole 646B. 1. Cyclammina pusilla Brady, Sample 105-646B-68X-3, 47-49 cm, 83X. 2a,b. Cyclammina pusilla Brady, Sample 105-646B-69X-1, 33-35 cm, 83X. 3. Cyclammina cancellata Brady, Sample 105-646B-78X-2, 40-42 cm, 28X. 4. Haplophragmoides sp., Section 105-646B-47X, CC, 47X. 5. Trochamminoides sp., Sample 105-646B-68X-3, 47-49 cm, 83X. 6. Trochamminoides sp., Sample 105-646B-67X-2, 111-113 cm, 83X. 7. Ammosphaeroidina sp., Section 105-646B-47X, CC, 50X. 8. Trochamminoides sp., Sample 105-646B$67 \mathrm{X}-2,111-113 \mathrm{~cm}, 125 \mathrm{X}$. 9. Karreriella conversa (Grzybowski), Sample 105-646B-67X-2, 111-113 cm, 83X. 10. Martinotiella sp., Section 105646B-49X, CC, 83X. 11. Martinotiella sp., Sample 105-646A-62X-5, 54-56 cm, 33X. 12. Siphotextularia sp., Sample 105-646B-73X-2, 58-60 cm, $83 \mathrm{X}$. 